\title{
The Positive Effect of Women's Education on Fertility in Low-Fertility China
}

\author{
Shuang Chen ${ }^{1}$ (1)
}

Received: 30 November 2020 / Accepted: 27 December 2021 / Published online: 7 February 2022

(c) The Author(s) 2022

\begin{abstract}
Despite pervasive evidence of more educated women having lower fertility, it remains unclear whether education reduces women's fertility. This study presents new evidence of the causal effect of women's education on fertility from China, where fertility has remained below the replacement level since the early 1990s. To account for endogeneity, the study exploits the timing and varying intensity of China's higher education expansion as exogenous sources of increase in women's education. Using data from China General Social Survey (2010-2012), findings show that each year of women's education induced by the higher education expansion increases the number of children ever born by $10 \%$. According to the average marginal effects, each additional year of women's education increases the number of children ever born by 0.14 , decreases the probability of having no children by 3 percentage points, and increases the probability of having two or more children by 4 percentage points. Two mechanisms drive the positive effect of education: first, education does not cause an increase in the mean age at first marriage; second, among ever-married women, education increases their demand for children. Findings from this study have important implications for China and other low-fertility developing countries.
\end{abstract}

Keywords Women's education $\cdot$ Fertility $\cdot$ China $\cdot$ Low fertility

\section{Introduction}

Extensive research has studied the relationship between women's education and fertility in developing countries (Bongaarts, 2003; Cleland, 2002; Cleland \& Rodriguez, 1988; Cochrane, 1979; Martin, 1995). Although this literature has presented pervasive evidence that more educated women have lower fertility, it remains

Shuang Chen

s.chen114@1se.ac.uk

1 Department of Social Policy, London School of Economics and Political Science, Houghton Street, London WC2A 2AE, UK 
unclear whether education reduces women's fertility. The negative correlation between women's education and fertility may be entirely due to unobserved family background factors that determine both education and fertility (Kramarz et al., 2021; Neiss et al., 2002; Nisén et al., 2013; Rodgers et al., 2008; Tropf \& Mandemakers, 2017). More education may be a consequence (rather than cause) of lower fertility (Cohen et al., 2011; Marini, 1984; Stange, 2011). Due to unobserved heterogeneity and reverse causality, comparing the fertility of higher- and lower-educated women leads to a biased estimate of the effect of education on fertility, and taking it as causal evidence could yield misleading policy implications. Indeed, the few studies of the causal effect of women's education on fertility, set in both developing and developed contexts, have generated mixed evidence. While some demonstrate a negative causal effect (Cygan-Rehm \& Maeder, 2013; Fort et al., 2016; Kamhöfer \& Westphal, 2019; Osili \& Long, 2008; Sohn \& Lee, 2019), others find that the negative effect disappears (Breierova \& Duflo, 2004; Geruso \& Royer, 2018; Kan \& Lee, 2018; Kramarz et al., 2021; McCrary \& Royer, 2011; Monstad et al., 2008) or even reverses to positive (Braakmann, 2011; Fort et al., 2016) as soon as endogeneity of women's education is accounted for. This study presents new evidence of the causal effect of women's education on fertility in a low-fertility developing context.

Since the early 1990s, the total fertility rate (TFR) has remained below the replacement level in China (Cai, 2010; Feeney \& Yuan, 1994; Guo et al., 2019; Morgan et al., 2009; Zeng \& Hesketh, 2016; Zhao \& Zhang, 2018). Also during this period, women's educational opportunities have increased rapidly (Hannum, 2005; $\mathrm{Wu} \&$ Zhang, 2010; Yeung, 2013). Gender gaps in education have narrowed at the primary and secondary levels and reversed at the tertiary level (Hannum, 2005; Wu \& Zhang, 2010; Yeung, 2013). In contrast to the rapid growth in educational opportunities, however, women's disadvantages in the labour market have increased in terms of participation (Attané, 2012; Chi \& Li, 2014; Hare, 2016), earnings (Chi \& Li, 2014; Gustafsson \& Li, 2000; Zhang et al., 2008), as well as occupational segregation (Chen et al., 2013; He \& Wu, 2017; Zhang, 2013). Within the family, traditional gender ideologies and gendered division of labour remain unchanged (Ji et al., 2017; Ji, 2015a; Luo \& Chui, 2018; Pimentel, 2016; Qian \& Li, 2020; Zuo, 2003; Zuo \& Bian, 2001), further exacerbating women's disadvantages in the labour market and the work-family conflicts they face (Maurer-Fazio et al., 2007, 2011; Zhang et al., 2008; Zhang \& Hannum, 2015).

Previous research on the relationship between women's education and fertility in China is largely lacking, except for a few cross-sectional studies set in the 1980s or earlier (Lavely \& Freedman, 1990; Zhang, 1990). The current study is set in a period (2010-2012) by which TFR had remained below the replacement level for almost two decades. Even though the period precedes the announcement of a universal two-child policy (Zeng \& Hesketh, 2016), a large proportion of the population was already permitted to have more than one child (Gu et al., 2007; Zeng \& Hesketh, 
2016). ${ }^{1}$ Methodologically, this study exploits the timing and varying intensity of China's higher education expansion in 1999 as a natural experiment to estimate the causal effect of women's education on fertility.

\section{Theoretical Framework}

According to Easterlin's framework (Easterlin, 1975; Easterlin \& Crimmins, 1985), fertility is determined by the potential supply of children, demand for children, and cost of fertility regulation. Easterlin's original framework has been applied to examining the effect of women's education on fertility in developing countries (Cochrane, 1979; Mason, 1987). Here, I consider the two most relevant pathways in the Chinese context where contraceptive use is prevalent among women (Zheng et al., 2012): age at first marriage and demand for children. Later in the article, I discuss whether more educated women are also better able to translate their demand for children into fertility regulation and actual fertility.

\subsection{Age at First Marriage}

In theory, education delays women's entry into marriage for three reasons. First, because school enrolment and motherhood are often incompatible, longer school enrolment has a mechanical effect of postponing family formation and childbearing (Bhrolcháin \& Beaujouan, 2012; Black et al., 2008; Lappegård \& Rønsen, 2005; Neels et al., 2017). Second, according to Becker's economic theory of marriage $(1973,1991)$, more educated women have fewer gains from marriage, because higher earnings and labour market participation make the gendered division of labour within the household less advantageous. In many European countries and the USA, women's education is not associated or even positively associated with marriage, countering Becker's theory (Blossfeld \& Kiernan, 2019; Blossfeld \& Huinink, 1991; Isen \& Stevenson, 2010; Sweeney, 2002). However, in countries with more traditional family systems and a high degree of role differentiation by gender, negative associations between women's education and probabilities and rates of marriage continue to be found (Blossfeld \& Kiernan, 2019; Ono, 2003). Across East Asian societies, marriage is laden with various traditional expectations of and for women, including childbirth, caretaking, and housework (Ji, 2015b). In this context, for more educated women, gains from marriage are fewer and the cost of marriage is higher. Moreover, preferences for women to marry men of higher status than themselves remain strong and the spouse-selection criterion remains gender asymmetrical. Consequently, improvement in women's socioeconomic status relative to men's results in marriage market mismatches for higher-status women and lower-status men (Raymo \& Iwasawa, 2005; Raymo \& Park, 2020; Yu \& Xie, 2015). More educated women

\footnotetext{
${ }^{1}$ By the end of the 1990 s, only about a third of the population was estimated to be subject to a strict one-child policy (Gu et al., 2007). By 2007, in all provinces but one, couples who were both only-children themselves are permitted to have two children (Zeng \& Hesketh, 2016).
} 
may also find it harder to find men who share their values (Jones, 2007), particularly since more educated Chinese women increasingly adopt gender-egalitarian ideologies while men's values have been slower to change and have even become more traditional (Pimentel, 2016; Qian \& Li, 2020). Taken together, education is hypothesized to reduce fertility by delaying women's first marriage. ${ }^{2}$

Although many observational studies in China show that more educated women marry later (Ji \& Yeung, 2014; Piotrowski et al., 2016; Tian, 2013; Yeung \& Hu, 2016; Yu \& Xie, 2015), education cannot be said to cause later marriage. If women have taken into account the negative impact of education on marriage prospects when making educational decisions, the positive relationship between education and age at first marriage may be spurious, even if the theoretical pathways between education and later marriage were true. For example, previous research in China suggests that parents who believe that girls' wellbeing depends on a good marriage invest less in their daughters' education (Li \& Tsang, 2003), whereas some girls pursue more education as a conscious strategy to avoid early marriage (Seeberg, 2014). This means that higher and lower educated girls differ in unobserved ways that affect when they marry. In other words, more educated girls would have married later even without more education. Moreover, increased education could be a result of delayed entry into marriage or parenthood (Cohen et al., 2011; Field \& Ambrus, 2008; Marini, 1984; Stange, 2011), and reverse causality would also have led to an overestimation of the delaying effect of education.

\subsection{Demand for Children}

Education shapes women's demand for children by affecting their income and the cost of children (Becker, 1965, 1969; Leibenstein, 1974; Willis, 1973), and the net effect is ambiguous in theory. By increasing women's income, education allows women to afford more children. Besides women's own wages, education may also increase income from other sources (for example, their husbands' wages if more educated women marry more educated men). The income effect may be weakened if increased income leads parents to spend more on the "quality" of existing children rather than "quantity" (Becker, 1969; Becker \& Lewis, 1973; Becker \& Tomes, 1976). ${ }^{3}$ The income effect may also be offset by a negative substitution effect due to the increased cost of children. By increasing women's wages, education increases the value of women's time, and thus, the opportunity cost of raising children. In addition, as more educated women rely less on children for economic gains or oldage support (Mason, 1987), education decreases the value of children, further reducing the number of children women demand.

\footnotetext{
${ }^{2}$ Marriage is near-universal in China (Jones, 2007; Yeung \& Hu, 2016), and non-marital childbearing is extremely rare.

${ }^{3}$ Empirical evidence of a "quantity-quality tradeoff" is mixed (Angrist et al., 2010; Black et al., 2005; Kugler \& Kumar, 2017; Li et al., 2008; Ponczek \& Souza, 2012; Rosenzweig \& Wolpin, 1980; Rosenzweig \& Zhang, 2009).
} 
When women must choose between working and raising children, the negative substitution effect exceeds the income effect, and an inverse relationship between women's education and the demanded number of children is most commonly observed in empirical studies (Schultz, 1997). However, this relationship changes if childrearing does not entirely rely on women's time, for example, if women can purchase childcare services (Ermisch, 1989; Hazan \& Zoabi, 2015). Outsourcing a part of childrearing to childcare services essentially alters the cost of children from the woman's perspective (Ermisch, 1989; Hazan \& Zoabi, 2015). In this case, even though education still increases the value of women's time, it does not increase the cost of raising children as much (as if childrearing entirely relies on women's time), leading to a less negative or even positive effect on fertility (Ermisch, 1989; Hazan \& Zoabi, 2015). ${ }^{4}$ Consistent with the theoretical models, in Norway, thanks to increased access to heavily subsidized childcare facilities, the association between women's education and completed fertility has become less negative over time (Kravdal \& Rindfuss, 2008). In the USA where there is little or no government subsidies for childcare, Hazan and Zoabi (2015) demonstrate a $U$-shaped relationship whereby highly educated women, for whom the cost of childcare services relative to income is lower, have more children and work longer hours than women with intermediate levels of education. More broadly speaking, the negative effect of women's education on fertility is moderated or reversed if women's roles as workers and mothers are more compatible. Access to childcare is one way to reduce women's role incompatibility (Du \& Dong, 2013; Kravdal \& Rindfuss, 2008; Richter et al., 1994; Rindfuss \& Brewster, 1996; Wood et al., 2020). Labour market institutions also matter (Adserà, 2005, 2011; Ahn \& Mira, 2002; Brinton \& Oh, 2019). If education leads to women enjoying more gender-egalitarian couple arrangements and division of household labour, it can also contribute to a reversal in the educationfertility relationship from negative to positive (Anderson \& Kohler, 2015; EspingAndersen, 2017; Esping-Andersen \& Billari, 2015; Goldscheider et al., 2015).

\section{Endogeneity of Women's Education}

A major empirical challenge faced by research studying the effect of women's education on fertility is that women's education is endogenous. Higher- and lower-educated women may differ in unobserved ways that also affect their fertility (Amin \& Behrman, 2014; Neiss et al., 2002; Nisén et al., 2013; Rodgers et al., 2008; Tropf \& Mandemakers, 2017). Fertility and education decisions may be jointly made, and women who have or intend to have more children may discontinue education earlier (Cohen et al., 2011; Marini, 1984; Stange, 2011). In the Chinese context, the varying enforcement of family planning policies correlated with socioeconomic contexts (Cai, 2010; Gu et al., 2007) adds further challenges to estimating the causal effect of education.

\footnotetext{
${ }^{4}$ The conclusions hold even after taking into account the child quantity-quality interaction (Ermisch, 1989; Hazan \& Zoabi, 2015).
} 
One approach to studying the causal effect of education fertility is to compare identical twins who differ in education levels (Amin \& Behrman, 2014; Kramarz et al., 2021; Nisén et al., 2013; Rodgers et al., 2008; Tropf \& Mandemakers, 2017). Although the approach effectively controls for any unobserved family background factors, the effect of education on fertility may still be confounded by individual heterogeneity, that is, factors causing education to differ between twins may also cause the fertility differences. The within-twins approach may also be problematic in the Chinese context, as previous research found that couples misreport their children as twins to avoid the punishment for violating the one-child policy (Huang et al., 2016).

Another common approach exploits educational reforms as exogenous sources of change in women's education and obtains an instrumental variable (IV) estimate of the effect of women's education. Exploiting compulsory education law changes, studies have found a negative effect of women's education on fertility in Germany (CyganRehm \& Maeder, 2013) and England (Fort et al., 2016), a null effect in Norway (Monstad et al., 2008), UK (Geruso \& Royer, 2018) and Taiwan (Kan \& Lee, 2018), and a positive effect across Continental Europe (Austria, Denmark, France, Italy, and the Netherlands) (Fort et al., 2016) and in the UK (Braakmann, 2011). Two studies using higher education expansion as an exogenous increase in probabilities of women having a college degree found a negative effect on fertility in Germany (Kamhöfer \& Westphal, 2019) and South Korea (Sohn \& Lee, 2019). In Indonesia, Breierova and Duflo exploit the timing and varying intensity of a school construction program as exogenous sources of change in women's education and found no effect on the number of children ever born (Breierova \& Duflo, 2004 2004). Using a similar identification strategy, Osili and Long (2008) found a negative effect of women's education on the number of children born before age 25. Compared to the mixed evidence of the educational effects on completed fertility, there is more consistent evidence showing that women's education reduces teenage births (Black et al., 2008; Cygan-Rehm \& Maeder, 2013; Geruso \& Royer, 2018; Grönqvist \& Hall, 2013; Kurdar et al., 2018; Monstad et al., 2008). However, the negative effect on teenage births may not extend to later years (Geruso \& Royer, 2018; Kirdar et al., 2018; Monstad et al., 2008).

In this study, I exploit the timing of China's higher education expansion along with its regional variations in intensity as exogenous sources of change in women's education. The strategy is analogous to the ones used by previous studies in Indonesia (Breierova \& Duflo, 2004; Duflo, 2001, 2004), Nigeria (Osili \& Long, 2008), Taiwan (Chou et al., 2010), Malawi and Uganda (Andriano \& Monden, 2019) to study the causal effects of education on fertility, health, and labour market outcomes. The idea is that the expansion induces exogenous increases in women's education across cohorts and that regions where the expansion is more intense should see more increases in women's education. 


\section{Data and Method}

\subsection{Data}

This study draws on the 2010, 2011, and 2012 waves of the China General Social Survey (CGSS). The CGSS is the first nationwide, comprehensive, large-scale social survey in China, launched jointly by Renmin University and the Hong Kong University of Science and Technology (Bian \& Li, 2012). Because the Chinese government has introduced major changes to the "one-child" policy since the end of 2013, restricting the data to before 2013 ensures that the policy environment is relatively stable during the period of the current study. In other words, no period effect associated with the changing fertility policy confounds the educational effect. I restrict the sample to women born between 1971 and 1989 and who are aged at least 23 at the time of the survey. I matched the individuals in the survey with province-level data using the province of hukou registration. Table 1 presents the descriptive statistics of the variables used in the analysis. The average years of education attained by the women in the sample are about 10 years, with $26 \%$ having attained some tertiary education or above and $17 \%$ with a high school degree. These are broadly in line with education statistics from other data sources (OECD, 2020; UNESCO, 2020). "Appendix Table 6" provides additional descriptive statistics of the number of children ever born by educational levels.

\subsection{Measurement}

The main independent variable of interest is years of education, which is converted from the level of educational attainment reported by the respondent $(0$ years for no education or less than primary level, 6 years for primary school, 9 years for middle school, 12 years for high school including technical/vocational high school, 15 years for vocational/technical college, and 16 years for a 4-year college or postgraduate degree). The main outcome of interest is the number of children ever born. Two intervening variables are examined directly. One is the age at first marriage. The other is the demand for children among ever-married women, which is measured by the woman's answer to the question: "In the absence of the one-child policy, how many children do you wish to have?" Previous research has shown that this measure strongly predicts subsequent fertility behaviour in the Chinese context (Hermalin \& Liu, 1990; Jiang et al., 2015; Zheng, 2014). ${ }^{5}$ Because reported demand for children might be biased by the rationalization of the existing number of children, an additional measure of demand for children is whether the woman demands more than two children.

\footnotetext{
${ }^{5}$ Without the lead-in "In the absence of the one-child policy...", a conventional measure of fertility intention underestimates the "true" demand for children in the Chinese context, since respondents may simply restate government restrictions on family size or provide socially desirable answers (Feng, 2017; Hermalin \& Liu 1990; Merli \& Smith, 2002; Morgan et al., 2009).
} 
Table 1 Descriptive statistics of variables used in the analysis. Source: provincial-level data from China Statistical Yearbooks; individual-level data from China General Social Survey (CGSS) 2010, 2011 and 2012

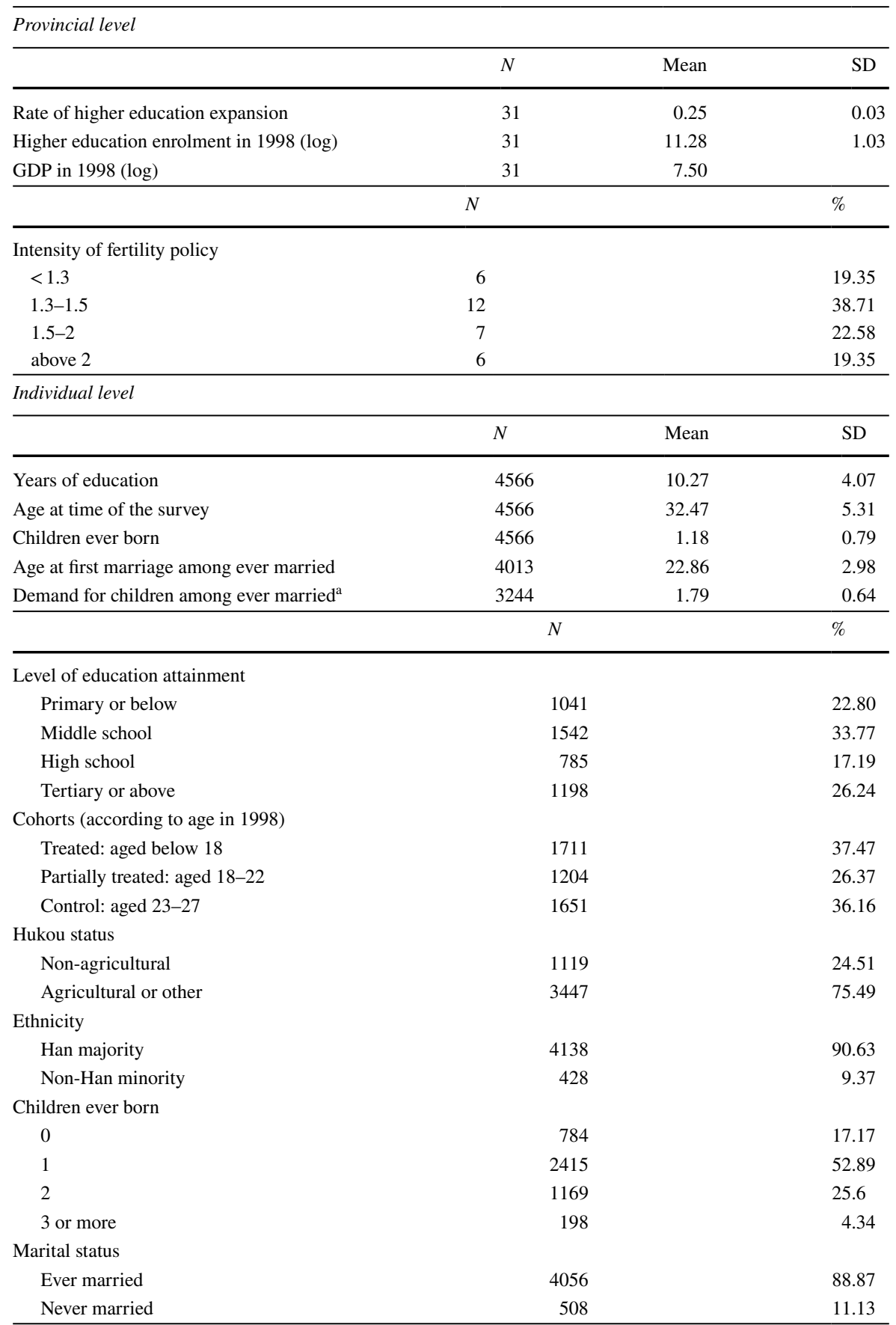

${ }^{a}$ The demanded number of children was not collected in the CGSS 2011 survey 


\subsection{Analytic Strategy}

\subsubsection{China's Higher Education Expansion}

Students wishing to go on to higher education in China take the annual college entrance examination (also known as Gaokao) generally at the end of high school. Admission quotas for each province, university, and subject are negotiated annually between universities and national and provincial authorities. The cutoff scores for entry into each university and department are determined after all the test scores are known. In June 1999, right before the annual college entrance examination took place, the Ministry of Education made a sudden announcement to increase the number of admissions from 1.08 million in 1998 to 1.56 million in 1999, a 44\% increase (Ministry of Education, 2004). The initial policy shock evolved into a sustained expansion until 2007. As illustrated in Fig. 1, between 1998 and 2007, the number of admissions to regular higher education institutions has seen more than a fivefold growth from 1.08 to 5.66 million. The higher education expansion has induced two sources of variation in women's education: (1) the increase in the number of admissions over time and (2) the varying intensity of the expansion across provinces. In other words, provinces where the higher education expansion is more intense should see greater increases in women's education across cohorts. The analytic strategy thus exploits the differential growths

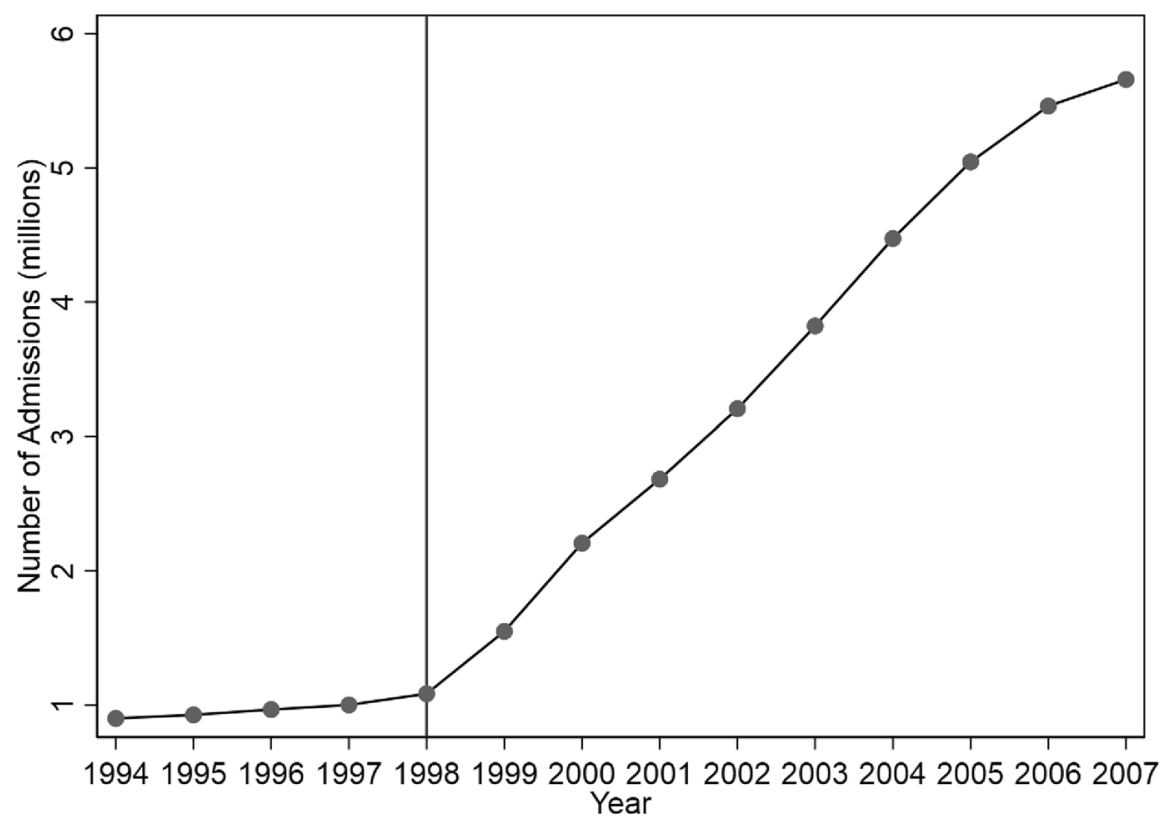

Fig. 1 Number of admissions to higher education institutions nationwide by year. Source: China Statistical Yearbooks (1994-2007) 
in women's education across provinces induced by the higher education expansion to identify the effect of women's education on fertility.

More specifically, given the modal age of taking the college entrance examination at 18, I define as "treated" cohort women who are aged below 18 in 1998. These individuals are most likely to benefit from the sudden increase in admissions to higher education. I define as "control" cohort women who are aged 23-27 in 1998. These individuals most likely had left school before the expansion started, and hence had missed the expansion. Due to the variation in school-starting ages and prevalent grade skipping and repetitions, the actual age at which a student takes the college entrance exam can vary. A minority of students may also decide to retake the exam the following year if they are unsatisfied with the outcome of their first attempt. For example, over $30 \%$ of the applicants who sat the college entrance examination in 1997 had graduated from high school the year before or even earlier (Ministry of Education, 1998). Therefore, I define a "partially treated" cohort that contains women aged between 18 and 22 in 1998. Women's education is expected to increase from the "control" cohort to the "partially treated" cohort and further to the "treated" cohort.

The intensity of the higher education expansion is measured by the annualized relative change in the number of admissions between 1998 and 2003, ranging from $16 \%$ in Beijing to $32 \%$ in Jiangxi province. In China, students are required to take the college entrance examination in the province of their hukou registration and subject to the admission quotas and the resulting cut-off scores specific to that province. The same requirements apply to migrant students even if they have been attending school in a different province. ${ }^{6}$ This institutional feature allows me to determine a woman's exposure to the intensity of the expansion by the province of her hukou registration. ${ }^{7}$ Together, the interaction terms between the cohort indicators and the province-specific rate of expansion form the instrumental variables for women's years of education.

Importantly, the expansion of higher education should not only increase attainment at the tertiary level but also the preceding levels of education. Research in China suggests that the perceived chance of admission to college affects decisions to drop out of the education system as early as the transition from middle school to high school (Loyalka et al., 2017; Yeung, 2013). Secondary level education in China mainly serves as a selection mechanism for tertiary education and prepares students for the college entrance exam ( $\mathrm{Li}$ et al., 2012). Research outside China has also shown that an increased likelihood of getting into college increases students' educational achievement and attainment at pre-collegiate levels (Akhtari et al., 2019;

\footnotetext{
${ }^{6}$ Reforms to the hukou systems have made possible changes of hukou location (or place of registration); however, data from 2000 census suggest that the total number of individuals who have changed their hukou from one province to another, i.e. permanent interprovincial migrants, account for only $0.36 \%$ of the total population (Fan, 2005; Sun \& Fan, 2011).

7 Although a number of public universities directly under the administration of the Chinese central government recruit students from across the country, the main driver of the higher education expansion is public universities under the jurisdiction of the provincial governments and private institutions, which admit majority of the students from within the province (Carnoy et al., 2013, 49).
} 
Khanna, 2019). Therefore, higher education expansion should not only benefit high school graduates but also incentivize students at lower levels of education to obtain more education.

\subsubsection{Model Specifications}

For the main outcome, children ever born, denoted $Y_{i j k}$, I estimate a Poisson model with multiplicative errors:

$$
Y_{i j k}=\exp \left(\alpha_{j}+\beta_{k}+\delta \mathrm{ED}_{i j k}+x_{i j k}^{\prime} \gamma+\tau_{i j k}\right)
$$

where $\mathrm{ED}_{i j k}$ denotes the years of education attained by individual $i$ with hukou registered in province $j$ and birth cohort $k . \alpha_{j}$ is province fixed effect, which controls for any time-invariant provincial characteristics (observed or unobserved). $\beta_{k}$ is a 1 -year birth cohort fixed effect, which captures trends in women's education not associated with the timing of the intensity of the higher education expansion. $x_{i j k}^{\prime}$ is a vector of covariates. Because the year of education, $\mathrm{ED}_{i j k}$, is endogenous, I identify its effect using instrumental variables, specified as follows:

$$
\mathrm{ED}_{\mathrm{ijk}}=\alpha_{j}+\beta_{k}+z_{j k}^{\prime} \lambda+x_{i j k}^{\prime} \gamma+\varepsilon_{i j k}
$$

where $z_{j k}^{\prime}$ is the instrumental variable, which is a vector of interaction terms between the cohort indicators (treated, partially treated) and the intensity of the expansion of province $j$, measured by the 5-year expansion rate in the number of admissions from 1998 to 2003.

For the cohort-intensity interactions to be a valid instrument for women's education, a key assumption is that trends in women's education would be the same in high-intensity and low-intensity provinces even in the absence of higher education expansion. There remain two potential threats to the "parallel trends" assumption. First, provinces with a lower baseline level of tertiary enrolment may see faster growth in women's education even without the higher education expansion. Similarly, the rising demand for education may have been driven by economic growth rather than the higher education expansion, and more admission quotas may have been allocated to provinces where women's education was increasing anyway. Second, the treated cohort of women was also exposed to the "one-child" policy introduced in 1979. Since declines in family sizes may also increase educational attainment due to the "quantity-quality trade-off" (Li et al., 2008), women's education may have grown faster in some provinces than others due to the varying intensity of the one-child policy rather than that of the higher education expansion. Therefore, I include in the vector of covariates, $x_{i j k}^{\prime} \gamma$, the interactions between the cohort indicators and the number of tertiary enrolments in 1998, the provincial GDP in 1998, and the one-child policy intensity measure derived from $\mathrm{Gu}$ et al. (2007). By including these covariates, I further relax the identification assumption by letting the trends in women's education differ across provinces. In addition, to increase the precision of the estimates, I include three 
Table 2 Effect of higher education expansion on women's years of education: coefficients on the interactions between cohorts and provincial rate of expansion from linear regression models (base category is "Rate of expansion $\times$ control")

Years of education

(1)

(2)

(3)

\begin{tabular}{llll}
\hline Rate of expansion $\times$ cohorts & & & \\
Rate of expansion $\times$ partially treated & 5.318 & $5.866 \dagger$ & $9.382^{* *}$ \\
& $(3.209)$ & $(2.956)$ & $(2.902)$ \\
Rate of expansion $\times$ treated & $14.39 * * *$ & $15.63 * * *$ & $21.80^{* * *}$ \\
& $(3.223)$ & $(2.889)$ & $(3.908)$ \\
$F$-statistics & $10.84 * * *$ & $15.80^{* * *}$ & $15.56 * * *$ \\
Covariates & & & Yes \\
Age at the time of the survey & No & Yes & Yes \\
Non-agricultural hukou & No & Yes & Yes \\
Han majority & No & Yes & Yes \\
Interaction between cohort and 1998 GDP & No & No & Yes \\
Interaction between cohort and 1998 enrolment & No & No & Yes \\
Interaction between cohort and fertility policy intensity & No & No & 4566 \\
$N$ & 4566 & 4566 & \\
\hline
\end{tabular}

Control cohorts are aged 23-27, partially treated cohorts are aged 18-22, and treated cohorts are aged below 18 in 1998, just before the start of the expansion. All model controls for 1-year birth cohort and province fixed effects. Standard errors are in parentheses and clustered by province

${ }^{\dagger} p<0.10, * * p<0.01, * * * p<0.001$. The F-statistic tests the hypothesis that the coefficients on the interaction terms are jointly zero

individual-level covariates: woman's age at the time of the survey (modelled by a series of dummy variables for each year of age), whether she has a non-agricultural hukou, and whether she is Han majority as opposed to an ethnic minority. Because the instrumental variables are on the cohort-province level, controlling for these individual-level characteristics should not affect the validity of the instrument.

To estimate the effect of education on intervening variables, I use the same first stage specified in Eq. 2 to regress years of education on the instrumental variables. For age at first marriage, I change the Poisson model specified in Eq. 1 to a parametric survival model, which assumes that the survival time follows a log-normal distribution. Because age at first marriage is reported in years and some individuals have not yet married at the time of the survey, the model is estimated using interval regression, which is a generalized Tobit model for censored data (Cameron \& Trivedi 2009, p. 530; Conroy, 2005). Among ever-married women, to estimate the effect of education on the demand for children, I use the same Poisson model specified in Eq. 1 above. To estimate the effect of education on whether the individual demands more than two children, I replace the Poisson model in Eq. 1 with a Probit model. 


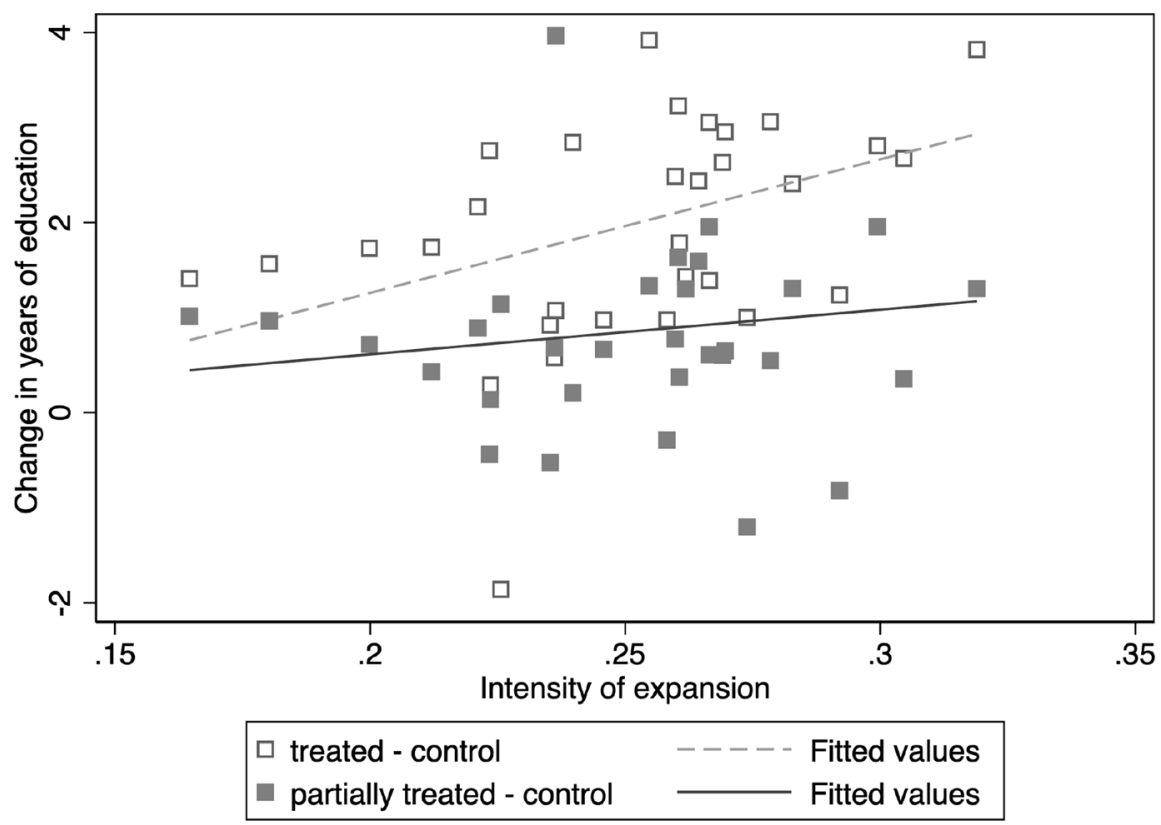

Fig. 2 Scatterplot of intensity of higher education expansion versus change in years of women's education (between control and partially treated cohorts, between control and treated cohorts) and two fitted lines using Eq. 2. Source: Author's calculation using data from China Statistical Yearbooks (1994-2007) and CGSS (2010-12)

\section{Results}

\subsection{First-Stage: Effects of Higher Education Expansion on Women's Education}

For the higher education expansion to be a valid instrument, first, it must induce changes in women's years of education. Specifically, provinces with higher intensity of expansion should see more increases in women's years of education. Table 2 presents the estimated effects of the higher education expansion on women's educational attainment using Eq. 2. The $F$-statistics test the null hypothesis that the coefficients on the interaction terms between cohorts and provincial rates of expansion are jointly zero. Model 1 is a baseline model containing only the province- and cohort-fixed effects, with no covariates. The direction and the magnitude of the coefficients are consistent with the identification assumption: provinces with more intense higher education expansion see greater increases in women's years of education across the control, partially treated, and treated cohorts. Model 2 controls for individual-level covariates such as age at the time of the survey, hukou type, and ethnicity. Because the instrumental variables used in this analysis are on the cohortprovince level, adding these individual-level covariates to the model should incur little change to the coefficients on the instrumental variables, but improve the precision of the estimates. This is indeed the case, as the coefficients in Model 2 are similar to those in Model 1, but the standard errors are smaller. Model 3 further relaxes 
the identification assumption by controlling for the interaction terms between the cohorts and the tertiary enrolment levels in 1998, provincial GDP in 1998, and the intensity of the "one-child" policy. This increases the magnitude of the coefficients on the instrumental variables.

Across all three models, the $F$-statistic is greater than 10 , indicating the strength of the instrument. According to Model 3, which is the full model used as the first stage in the following analyses, a province with a $10 \%$ point higher rate of expansion sees 0.9 additional years of increase in women's education between the control and partially treated cohorts, and over two additional years of increase between the control and treated cohorts. Figure 2 visualizes the first-stage results by plotting the intensity of the higher education expansion versus the observed change in women's years of education and overlaying the scatterplot with fitted lines using estimates from Model 3. Consistent with the identification assumption, the figure illustrates that provinces with higher rates of expansion have seen more increase (or less decrease) in women's years of education across cohorts, and the slope of the fitted line for changes between the control and treated cohorts is steeper than that for changes between the control and partially treated cohorts. "Appendix Table 7" further illustrates that the higher education expansion not only increases women's probability of completing tertiary education but also increases their probabilities of completing high school and middle school. Consistent with prior research in and outside China (Akhtari et al., 2019; Khanna, 2019; Loyalka et al., 2017), this means that increased admission to higher education not only benefits high school graduates but also increases the educational attainment of students at lower levels of education.

Another assumption required for the instrument to be valid is that the higher education expansion induces exogenous changes in women's education. In the Appendix, I present sensitivity analyses that attest to the exogeneity assumption. The exogeneity assumption first implies that, in the absence of the higher education expansion, trends in women's education should be the same between high-intensity and low-intensity provinces. I conduct a placebo test estimating the effect of the higher education expansion on the change in the education of women aged 28-32 in 1998 and those aged 23-27 in 1998. As expected, I find no effect on these cohorts of women who were exposed to the higher education expansion. The exogeneity assumption also implies that higher education expansion should not affect women's fertility other than through increasing their years of education. In the sensitivity analysis presented in the Appendix, I discuss the potential threats. I present several direct and indirect tests, showing that the effect of women's education found in this study is through increased years of education, not through changes in men's education, quality of education, two-child policy eligibility, or any direct effect, lending support to the exclusion restriction assumption.

\subsection{Number of Children Ever Born}

Table 3 presents results from a Poisson model and an IV-Poisson model estimated by a generalized method of moments estimators (Cameron \& Trivedi, 2013; Mullahy, 1997; Windmeijer \& Santos Silva, 1997). According to the Poisson model, 
Table 3 Estimated effect of women's education on children ever born

Table 4 Estimated effect of women's education on age at first marriage

\begin{tabular}{lll}
\hline & \multicolumn{2}{l}{ Children ever born } \\
\cline { 2 - 3 } & $(1)$ & $(2)$ \\
& Poisson & IV-Poisson \\
\hline Years of education & $-0.0436^{* * *}$ & $0.0982^{*}$ \\
Hausman test & $(0.00404)$ & $(0.0449)$ \\
Overidentification test & & $10.05^{* *}$ \\
$N$ & & 0.861 \\
\hline
\end{tabular}

Standard errors are in parentheses

All models control for 1-year birth cohort and province fixed effects, age at the time of the survey, non-agricultural hukou, interactions between cohorts and provincial level GDP in 1998, tertiary enrolment in 1998, and fertility policy intensity

${ }^{*} p<0.05, * * p<0.01, * * * p<0.001$

\begin{tabular}{lll}
\hline & \multicolumn{2}{l}{ Age at first marriage (log) } \\
\cline { 2 - 3 } & $(1)$ & $(2)$ \\
& Interval regression & $\begin{array}{l}\text { Interval } \\
\text { regression } \\
\text { with IV }\end{array}$ \\
\hline Years of education & $0.0140 * * *$ & -0.00912 \\
Correlation between errors & $(0.000605)$ & $(0.00766)$ \\
$N$ & 4525 & $\begin{array}{l}0.505 * * * \\
4525\end{array}$ \\
\hline
\end{tabular}

Standard errors are in parentheses and clustered by province

All models control for 1-year birth cohort and province fixed effects, age at the time of the survey, non-agricultural hukou, interactions between cohorts and provincial level GDP in 1998, tertiary enrolment in 1998, and fertility policy intensity

$* * * p<0.001$

women's education is negatively associated with the number of children ever born. As soon as the endogeneity of education is accounted for in the IV-Poisson model, the coefficient flips from negative to positive: an additional year of education increases the number of children ever born by $10 \%$. The Hausman test for endogeneity is statistically significant, meaning that education is indeed endogenous and that the Poisson model is inconsistent. Using the estimate from the IVPoisson model, I calculate the average marginal effects of education: each year of education induced by the higher education expansion increases women's number of children ever born by 0.14 , decreases the probability of having no children by 3 percentage points, and increases the probability of having two or more children by 4 percentage points. 
Table 5 Estimated effect of women's education on demand for children and whether demanding more than two children

\begin{tabular}{lll}
\hline & \multicolumn{2}{l}{ Demanded number of children } \\
\cline { 2 - 3 } & $(1)$ & $(2)$ \\
& Poisson & IV-Poisson \\
\hline Years of education & $-0.00852^{*}$ & 0.0106 \\
Hausman test & $(0.00403)$ & $(0.0216)$ \\
Overidentification test & & 0.813 \\
$N$ & 3244 & 1.15 \\
\hline & Demand more than two children & 3244 \\
\cline { 2 - 3 } & $(1)$ & $(2)$ \\
\hline Years of education & Probit & IV-Probit \\
\hline Wald test of exogeneity & $-0.0429 * * *$ & $0.201^{* *}$ \\
$N$ & $(0.0139)$ & $(0.0632)$ \\
\hline
\end{tabular}

Standard errors are in parentheses and clustered by province

All models control for 1-year birth cohort and province fixed effects, age at the time of the survey, nonagricultural hukou, interactions between cohorts and provincial level GDP in 1998, tertiary enrolment in 1998, and fertility policy intensity

$* p<0.05, * * p<0.01, * * * p<0.001$

\subsection{Mechanisms}

\subsubsection{Age at First marriage}

Table 4 presents the estimated effect of education on the logarithm of age at first marriage. According to the interval regression model (Column 1 Table 4), an additional year of education is associated with $1.4 \%$ older age at first marriage. However, the positive association disappears when an extended interval regression model with endogenous covariates is estimated (Column 2 Table 4). The correlation between errors from the structural equation (Eq. 1) and the first-stage equation (Eq. 2) is positive and significantly different from zero, meaning that education is endogenous.

\subsubsection{Demand for Children}

Table 5 presents models estimating the effect of education on the number of children demanded among ever-married women. The Poisson model indicates a slight negative effect of education on demand for children. However, in the IV Poisson model, the educational effect is positive, albeit not statistically significant. It is possible that responses to the demanded number of children are biased by the rationalization of children already had or the varying eligibility to have 
one or two children (Hermalin \& Liu, 1990; Zhenzhen et al., 2009), which could have attenuated the estimated effect. To account for this possibility, the bottom panel of Table 5 presents the estimated effect on whether the individual demands more than two children. Consistently, while in the Probit model, an additional year of education is associated with a lower probability of demanding more than two children, the direction of the coefficient flips in the IV-Probit model: higher educational attainment significantly increases the probability of demanding more than two children. Both results suggest that, among ever-married women, education increases their demand for children.

\section{Discussion}

\subsection{Interpreting the Positive Causal Effect of Education}

Women's education is negatively associated with the number of children ever born, however, as soon as endogeneity of education is accounted for, I find a positive causal effect of women's education: each additional year of women's education induced by the higher education expansion increases women's number of children ever born by $10 \%$. According to the average marginal effects, each year of women's education increases the number of children ever born by 0.14 , decreases the probability of having no children by 3 percentage points, and increases the probability of having two or more children by 4 percentage points. These results are consistent with those of Fort and colleagues (2016): their findings from Continental Europe demonstrate that each additional year of women's education induced by the compulsory education reforms increases the number of biological children by $0.2-0.3$ and decreases childlessness by $5-11 \%$ points. That the negative correlation between women's education and the number of children ever born flips to positive in the IV-Poisson model is consistent with the expected direction of bias: if women who want to have more children also obtain less education, simply comparing the fertility of women with different education attainment overestimates the negative effect of education.

It is important to note that the IV estimator estimates the local average treatment effect (Angrist, 2001; Angrist et al., 1996; Imbens, 2014; Imbens \& Angrist, 1994), which is the effect of education on "compliers", or women who obtain more education because of the higher education expansion. While the local average treatment effect cannot be extrapolated to the overall population, for policymakers, it is more relevant than the average effect in the population, because the "compliers" are a subpopulation who are impacted by the policy reform (J. D. Angrist \& Pischke, 2009; Card, 2001). Supply-side educational reforms tend to affect the schooling of individuals with relatively high returns to education (Card, 2001). Specifically, compliers of China's higher education expansion have been shown to come from the more developed Eastern region, urban areas, and less likely to be ethnic minorities (Li \& Xing, 2010). In this view, the positive effect of education found in this study echoes 


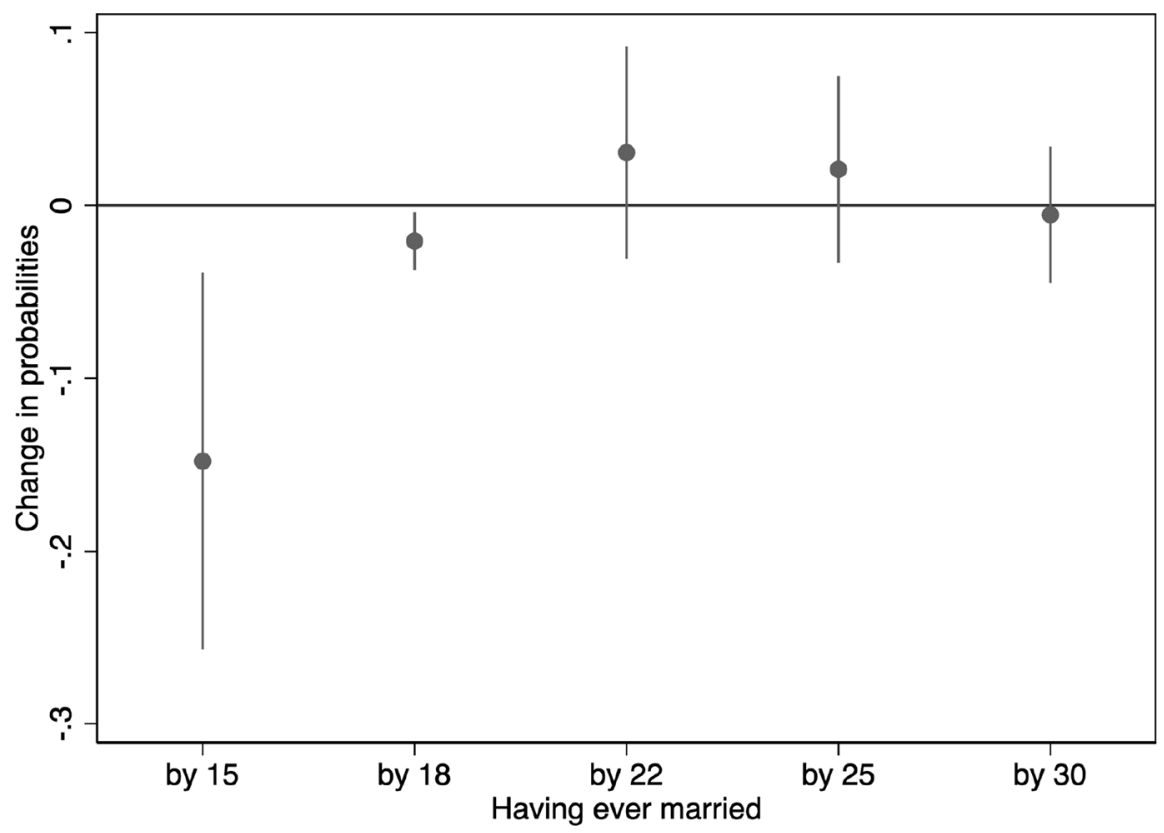

Fig. 3 Average marginal effects of women's education on probabilities of having entered first marriage by age 15, 18, 22, 25, and 30, estimated from IV-Probit models. Source: Author's calculation

findings from the US that college completion increases fertility among the more advantaged women (Brand \& Davis, 2011).

\subsection{Education Does Not Increase Mean Age at First Marriage}

Why does women's education increase the number of children ever born? The first mechanism revealed by the analyses is that women's education does not increase the mean age at first marriage. Even though the study has found a strong correlation between women's education and later age at marriage, the effect disappears as soon as the endogeneity of education is accounted for. This is consistent with the expectation that the correlation between more education and later age at marriage is drive by selection and reverse causality. Several studies set outside China have also shown that the relationship between education and postponement of marriage or first birth is not causal (Cygan-Rehm \& Maeder, 2013; Fort et al., 2016; Kan \& Lee, 2018; Lefgren \& McIntyre, 2006; Neiss et al., 2002; Rodgers et al., 2008; Tropf \& Mandemakers, 2017). Specifically, studies using within-identical twin models and set in the US, Denmark, and the UK illustrate that the association between education and later age at first birth is largely, if not completely, due to the unobserved family background factors that are related to both education and entry into parenthood (Neiss et al., 2002; Rodgers et al., 2008; Tropf \& Mandemakers, 2017). 
To further elucidate the null effect of women's education on mean age at first marriage, I use IV-Probit models to estimate the causal effects of women's education on the probability of having entered first marriage by age 15, 18, 22, 25, and 30, respectively. Figure 3 plots the average marginal effects calculated using estimates from these IV-Probit models. According to Fig. 3, women's education significantly reduces the probabilities of having ever married by age 15 and 18 , and yet, has a slightly positive, albeit non-significant, effect on probabilities of having ever married by age 22 and 25. By age 30, education makes no difference in probabilities of having ever married. This result suggests that the lengthening of school years does indeed delay marriage for women who would otherwise get married before age 18, consistent with theoretical predictions (Bhrolcháin \& Beaujouan, 2012; Black et al., 2008; Lappegård \& Rønsen, 2005; Neels et al., 2017). At the same time, however, Fig. 3 indicates a "catch-up" effect whereby women who postpone their marriage due to longer school enrolment get married as soon as the additional years of schooling are finished. As a result, despite reducing the probability of early marriage, women's education does not cause an overall increase in the mean age at first marriage. Outside China, research has similarly found that even though education reduces early marriage or births, the negative effect may not extend to later years (Anderberg \& Zhu, 2014; Fort, 2012; Geruso \& Royer, 2018; Kırdar et al., 2018; Monstad et al., 2008).

\subsection{Education Increases Demand for Children}

The analyses also reveal that education increases the demand for children among married women. As discussed earlier, women's education can have a positive effect on demand for children if women's roles as mother and worker are not incompatible. For example, with access to purchased childcare, more educated women not only have more children but also work more (Ermisch, 1989; Hazan \& Zoabi, 2015; Rindfuss \& Brewster, 1996; Wood et al., 2020). In “Appendix Table 8", I show that education indeed increases ever-married women's probability of being employed, and among those employed, each additional year of education increases their hourly wages by $15 \%$ according to the OLS model and $23 \%$ according to the 2SLS model. In other words, more educated women not only demand more children but also participate in the labour market more and earn higher wages. This is consistent with previous research from China, showing that higher-income women who can afford private childcare are better able to combine work and childrearing, while lowerincome women are disproportionately disadvantaged by the work-family conflict (Ding et al., 2009; Du \& Dong, 2013; Ji et al., 2017).

Education can also increase women's demand for children by increasing their non-wage income. Compared to women's own wages, the effect of non-wage income is less confounded by the opportunity cost of childrearing (Schultz, 1997). Particularly, if more educated women marry more educated men, as is the case in China (Han, 2010; Qian \& Qian, 2014), education increases husbands' wages. The top panel of "Appendix Table 9" estimates the effect of education on women's education on non-wage income, that is, total household income minus women's wage income. 
This includes but is not limited to husbands' wage income. Education increases the woman's non-wage income by $7.5 \%$, and the estimate is even greater in the twostage least squares (2SLS) model than in the OLS model. Moreover, using the husband's education as a proxy for his earning potential, the bottom panel of "Appendix Table 9" further reveals that each year of women's education increases the spouse's education by 0.57 years.

If the higher education expansion and a sudden increase in the college-educated entrants into the labour market drives down the wage premium on tertiary education and increases unemployment rates (Knight et al., 2017), education may have increased the demand for children by reducing women's labour market participation and wages. That education increases women's employment and hourly wages as shown before ("Appendix Table 8") rules out this explanation. It also means that the increased non-wage income has not led women to withdraw from the labour market or switch to lower-paying jobs.

Another alternative explanation is that the measure of demand for children is not reliable in China with policy restrictions on family size, which may have biased the estimated effect of education. For example, more educated women may be less subject to social desirability bias when interviewed about their demand for children, and thus less likely to underreport their true demand. To rule out this possibility, I examine responses to a different survey question which is likely subject to the same response bias. In the 2010 CGSS survey, respondents were asked how much they agree with the statement "the number of children one has is a personal matter. The government should not intervene." If more educated women were less subject to response bias, they would be more likely to agree with the statement. Results from a multinomial logit model ("Appendix Table 10") show that more educated women are no more or less likely than less educated women to agree or disagree with the statement. Therefore, there is no indication that the positive educational effect on the demand for children is due to response bias.

Taken together, the additional analyses presented here reveal that education not only increases women's demand for children but also their labour market participation and wages. This suggests that more education may have enabled women to better combine work and childrearing. Education has also increased women's non-wage income, including their husband's wages through assortative mating, which may also help explain the positive effect of education on demand for children.

\subsection{Education Increases Women's Resources Relative to Their Husbands'}

If women had no say in the fertility decision-making process, their demand for more children would be irrelevant for their actual fertility. Previous research in China indicates that women with more education (Hu \& Yeung, 2019) or income (Qian \& Jin, 2018; Shu et al., 2013) relative to their husbands enjoy more power in making decisions regarding fertility and childrearing. Here, I investigate if education increases women's resources relative to their husbands.' "Appendix Table 11" illustrates that more educated women enjoy more resources relative to their husbands, measured by 
both education and income: education increases the probability of the woman having equal or more education than her husband, as well as the ratio of the woman's income to her husband's. To the extent that relative resources determine a woman's fertility decision-making power (Hu \& Yeung, 2019; Qian \& Jin, 2018; Shu et al., 2013), this result suggests that education may have allowed women to better achieve their demand for children.

Of course, relative resources are not the only determinant of women's decisionmaking power (Bittman et al., 2003; Cheng, 2019; Ferree, 1990; Shu et al., 2013). Whether a woman can translate her demand for children into contraceptive behaviours and actual fertility also depends on her husbands' demand for children, disagreement between her and her husband's demands, and communications between the couple (Bankole \& Singh, 1998; Iacovou \& Tavares, 2011; Mason \& Smith, 2000; Riederer et al., 2019; Testa, 2012; Testa et al., 2014). Due to the lack of data, the current study is unable to investigate the effect of women's education on fertility decision-making and regulation further.

\section{Conclusions}

This study estimates the causal effect of women's education on the number of children ever born in low-fertility China. Exploiting the timing and varying intensity of China's higher education expansion, the study shows that each additional year of women's education increases women's number of children ever born by $10 \%$. According to the average marginal effects, each additional year of women's education induced by the expansion increases the number of children ever born by 0.14 , decreases the probability of having no children by 3 percentage points, and increases the probability of having two or more children by 4 percentage points. The study further reveals two key mechanisms underlying the positive effect of women's education: education does not increase women's mean age at first marriage; among ever-married women, education increases their demand for children.

It is important to note that the outcome examined in this study is the number of children ever born, not completed cohort fertility. Given that the more educated women are also younger at the time of the survey, the effect on completed cohort fertility might be even more positive. Moreover, the effect estimated here is a local average treatment effect (Angrist, 2001; Angrist et al., 1996; Imbens, 2014; Imbens \& Angrist, 1994) on women who obtain more education because of the higher education expansion, which cannot be extrapolated to the overall population. In addition, although the current study provides some suggestive evidence that education allows women to better achieve their demand for children, future research should investigate more directly whether education increases women's fertility decisionmaking power, the role of their husbands, and the extent to which women's demand for children translates into contraceptive behaviours and realized fertility.

Findings from this study have important policy implications for China. First, the positive causal effect of women's education means that China's fertility would have been even lower without the major progress in women's education over the past decades. Previous research shows that the low period fertility in China has been 
driven by declines in first births (due to either delay in first births or increases in childlessness) offsetting the increases in second births (Guo et al., 2019; Zhao \& Zhang, 2018). This study estimates that each additional year of women's education induced by the higher education expansion has increased the probability of having at least one child by 3 percentage points and the probability of having two or more children by 4 percentage points. Second, the positive causal effect of women's education implies that the current low fertility may not be irreversible. More specifically, education is shown to have increased women's demand for children, not only by raising their income but also by reducing the work-family conflict they face. This echoes previous studies from China citing the high cost of childrearing as the key explanation for low fertility preferences, including the direct cost of education, lack of childcare provision, and the negative impact on women's career (Basten \& Jiang, 2015; Merli \& Morgan, 2011; Zeng \& Hesketh, 2016; Zhenzhen et al., 2009). Finally, findings from this study help illustrate why the transition from the "onechild" policy to a universal two-child policy has achieved a limited impact on raising fertility (Attané, 2016; Basten \& Jiang, 2015; Guo et al., 2019; Zhao, 2015). While low fertility can be reversed, merely allowing women to have more children is insufficient without increased support for families or measures to reduce the work-family conflict women face.

Is the positive effect of women's education on fertility unique to low-fertility China? A positive causal effect of women's education on fertility has previously been found in Continental Europe (Fort et al., 2016) and the UK (Braakmann, 2011). While causal studies are few, cross-sectional studies from low-fertility Europe have found countries and subregions where more educated women have higher cohort fertility (Nisén et al., 2021), higher rates of second or higher-order births (Hoem \& Hoem, 1989; Klesment et al., 2014; Kravdal, 1992; Wood et al., 2014, 2020), and higher fertility intentions (Testa, 2014). The negative correlation between women's employment and fertility has also reversed in recent cohorts (Adserà, 2005; Ahn \& Mira, 2002). It remains to be seen whether the positive causal effect of education on fertility found in China generalizes to other developing contexts, but the few existing studies suggest that the compatibility between work and childrearing has become a key determinant of women's fertility in other low-fertility developing countries, too. For example, in Brazil, gender equality and the ability to combine work and childrearing are found to be positively associated with higher-order births (Castanheira $\&$ Kohler, 2017). In urban Thailand, the availability of alternative childcare arrangements for the firstborn has been shown to predict the probability of having a second child (Richter et al., 1994), and university-educated women now have the highest level of fertility intentions (Buathong et al., 2017). As more developing countries are expected to reach below-replacement fertility levels in the near future (United Nations et al., 2019), there is a compelling need for future research to better understand the effect of women's education on fertility and help address the policy challenges posed by low fertility in the developing world. 


\section{Appendix}

\section{Sensitivity Analysis}

\section{Placebo Test}

As discussed before, a key assumption for the instrumental variables to be valid is that, in the absence of the higher education expansion, trends in women's education would not differ between high-intensity and low-intensity provinces. To further ensure that the differential growths in women's education across provinces in the first-stage results are due to the higher education expansion rather than unobserved province-specific time-varying factors, I conduct a placebo experiment: I estimate the effect of the higher education expansion on the change in women's education between the cohort aged 28-32 in 1998 and the cohort aged 23-27 in 1998. The expansion should have no effects on these cohorts of women because they had completed education before the expansion started. "Appendix Table 12" fits the same first-stage models on these two cohorts. A significant coefficient on the interaction term between cohort indicator and intensity of the expansion would imply either reverse causality (i.e. pre-existing trends in women's educational attainment determines the province-specific intensity of higher education expansion) or that there are unobserved province-specific time-varying factors that have confounded the relationship between the higher education expansion and the trends in women's education. "Appendix Table 12" shows that the estimated coefficient is not statistically significant in either of the three models, meaning that without the higher education expansion, the trends in women's education between cohorts do not differ systematically between the high- and low-intensity provinces.

\section{Exclusion Restriction}

The exogeneity of the instrument also implies exclusion restriction, that is, higher education expansion does not affect women's fertility other than through increasing their educational attainment. There are three main threats to this assumption. First, if higher education expansion affects men's educational attainment too, it may affect women's fertility outcomes not only through increasing their education but also through increasing the education of men. Second, higher education expansion may affect the quality of education women receive, and in turn, their fertility outcomes. Finally, the instrumental variables could have a direct influence on women's fertility: for example, if provinces with more intense higher education expansion also have more intense enforcement of the one-child policy, then women born in these provinces are more likely to be only children and marry men who are only children. Because couples in which both partners are only-children are permitted to have two children (Zeng \& Hesketh, 2016), these women may have more children not because they have obtained more education, but because they are more likely to be eligible to have two children. 
Table 6 Descriptive statistics: number of children ever born by the level of educational attainment

\begin{tabular}{|c|c|c|c|c|}
\hline & \multicolumn{4}{|c|}{ Level of educational attainment } \\
\hline & Primary or below & Middle school & High school & Tertiary or above \\
\hline $\begin{array}{l}\text { Mean number of } \\
\text { children ever born }\end{array}$ & 1.75 & 1.32 & 0.98 & 0.64 \\
\hline \multicolumn{5}{|l|}{ By category (\%) } \\
\hline 0 & 3.46 & 6.29 & 19.36 & 41.65 \\
\hline 1 & 35.35 & 58.82 & 64.71 & 52.75 \\
\hline 2 & 48.22 & 31.71 & 14.78 & 5.18 \\
\hline 3 or more & 12.97 & 3.18 & 1.15 & 0.42 \\
\hline$N$ & 1041 & 1542 & 785 & 1198 \\
\hline
\end{tabular}

Table 7 Effect of higher education expansion on women's educational attainment at each level: coefficients on the interactions between cohorts and provincial rate of expansion from Probit models (base category is "Rate of expansion $\times$ control cohorts")

\begin{tabular}{lllll}
\hline \multicolumn{4}{l}{ Educational attainment by level } \\
\cline { 2 - 5 } & $(1)$ & $(2)$ & $(3)$ & $(4)$ \\
& Tertiary & High school & Middle school & Primary school \\
\hline Rate of expansion $\times$ cohorts & & & & \\
Rate of expansion $\times$ partially treated & $3.839 \dagger$ & 3.876 & $3.642^{* *}$ & 0.0791 \\
& $(2.165)$ & $(2.561)$ & $(1.294)$ & $(3.430)$ \\
Rate of expansion $\times$ treated & $6.791^{* * *}$ & $8.663 * * *$ & $11.11^{* * *}$ & 2.842 \\
& $(1.524)$ & $(2.542)$ & $(1.480)$ & $(4.013)$ \\
$\chi^{2}$ statistic & $23.95^{* * * *}$ & $19.43^{* * *}$ & $56.51 * * *$ & 0.64 \\
$N$ & 4566 & 4566 & 4460 & 4025 \\
\hline
\end{tabular}

Standard errors are in parentheses and clustered by province

Control cohorts are aged 23-27, partially treated cohorts are aged 18-22, and treated cohorts are aged below 18 in 1998, just before the start of the expansion. All models control for 1-year birth cohort and province fixed effects, age at the time of the survey, non-agricultural hukou, interactions between cohorts and provincial level GDP in 1998, tertiary enrolment in 1998, and fertility policy intensity

The $\chi^{2}$-statistic tests the hypothesis that the coefficients on the interaction terms are jointly zero ${ }^{\dagger} p<0.10, * * p<0.01, * * * p<0.001$

"Appendix Table 13" presents direct evidence of the effect of higher education expansion on men's level of education. At none of the levels of education is the joint hypothesis test significant at the $95 \%$ level. That higher education expansion increases girls' educational opportunity at tertiary, high school, and middle school levels (as shown in "Appendix Table 7") but has a limited effect on boys' educational opportunity suggests that the chance of college admission might have presented a greater barrier to girls' educational opportunities than boys. Previous research has shown that academic achievement matters for parents' continuing 
Table 8 Estimated effect of education on women's employment and hourly wages among employed

\begin{tabular}{lll}
\hline & Employed & \\
\cline { 2 - 3 } & $(1)$ & $(2)$ \\
& Probit & IV Probit \\
\hline Years of education & $0.0439^{* * *}$ & 0.0262 \\
Wald test of exogeneity & $(0.0103)$ & $(0.101)$ \\
$N$ & & 0.06 \\
\hline & 4038 & 4038 \\
\cline { 2 - 3 } & Hourly wage $(\log )$ & $(2)$ \\
\hline Years of education & $(1)$ & 2 SLS \\
Wu-Hausman test of endogeneity & OLS & $0.203^{* * *}$ \\
Overidentification test & $0.136^{* * *}$ & $(0.0512)$ \\
$N$ & $(0.00854)$ & 1.664 \\
\hline
\end{tabular}

Standard errors are in parentheses and clustered by province

All models control for 1-year birth cohort and province fixed effects, age at the time of the survey, nonagricultural hukou, interactions between cohorts and provincial level GDP in 1998, tertiary enrolment in 1998 , and fertility policy intensity

$* * * p<0.001$

investment in girls' education but does not matter for boys' persistence in the education system (Zhang et al., 2007). Starting from the compulsory-level education, academically weak boys stay in school longer than academically weak girls (Brown \& Park, 2002). These findings suggest that girls' educational opportunities might be particularly sensitive to the perceived likelihood of getting into college compared to boys, which helps explain why higher education expansion has a greater effect on women's educational attainment.

To rule out the other potential threats to the exclusion restriction assumption, I conduct two falsification tests. First, as previously shown in "Appendix Table 7", the higher education expansion only affected women's attainment at the tertiary, high school, and middle school levels. It did not affect the probability of women attaining primary-level education. Therefore, for women with less than middle school education, their fertility outcomes should not have been affected by the higher education expansion, unless through factors other than their educational attainment. I estimate the effect of higher education expansion among the subsample of women with less than middle school education and show no effect on their number of children ever born (Column 2 of "Appendix Table 14"). The second falsification restricts the sample to women who had already left education before the expansion began. For those women, higher education expansion did not affect their educational attainment, and thus should not have affected their fertility, unless through other factors. Column 
Table 9 Estimated effect of women's education on non-wage income (log) and spouses' education

Non-wage income $(\log )$

(1) (2)

\section{OLS}

2SLS

Years of education

$0.0725 * * *$

$0.128 * *$

(0.00727)

$(0.0450)$

Wu-Hausman test of endogeneity

0.675

Overidentification test

$3.086+$

N

3615

3615

Spouse's years of education

(1)

OLS

2SLS

Years of education

$0.571 * * *$

$0.581 * * *$

(0.0153)

Wu-Hausman test of endogeneity

Overidentification test

$N$

Standard errors are in parentheses and clustered by province

All models control for one-year birth cohort and province fixed effects, age at the time of the survey, non-agricultural hukou, interactions between cohorts and provincial level GDP in 1998, tertiary enrolment in 1998, and fertility policy intensity

${ }^{\dagger} p<0.10, * * p<0.01, * * * p<0.001$

Table 10 Multinomial Logit Model estimates of the relationship between educational level and agreeing or disagreeing with the statement "The number of children one has is a personal matter. The government should not intervene" (base category is "neither agree nor disagree"). Source: CGSS (2010)

\begin{tabular}{lll}
\hline & $\begin{array}{l}\text { "The number of children one has } \\
\text { is a personal matter. The govern- } \\
\text { ment should not intervene" }\end{array}$ \\
\hline & $(1)$ & Disagree \\
\cline { 2 - 3 } Agree & \\
\hline Level of education (Primary or less) & 0.0692 \\
Middle school & 0.183 & $(0.264)$ \\
High school & $(0.243)$ & -0.103 \\
Tertiary and above & -0.0281 & $(0.296)$ \\
Constant & $(0.270)$ & $-0.425 \dagger$ \\
$N$ & -0.263 & $(0.258)$ \\
$N$ & $(0.233)$ & $1.128^{* * *}$ \\
& $2.112^{* * *}$ & $(0.197)$ \\
\end{tabular}

Standard errors are in parentheses

${ }^{\dagger} p<0.10,{ }^{*} p<0.05, * * p<0.01, * * * p<0.001$ 
Table 11 Estimated effect of women's education on relative education and income

Have equal or more education than spouse

(1)

Probit

IV Probit

Years of education

$0.149 * * *$

$0.180 *$

(0.00843)

(0.0659)

Wald test of exogeneity

0.17

$N$

3943

3943

Ratio of own income to spouse's income

(1)

OLS

2SLS

Years of education

$0.0216 * * *$

0.0725

$(0.00551)$

Wu-Hausman test of endogeneity

Overidentification test

$N$

Standard errors are in parentheses and clustered by province

All models control for 1-year birth cohort and province fixed effects, age at the time of the survey, nonagricultural hukou, interactions between cohorts and provincial level GDP in 1998, tertiary enrolment in 1998 , and fertility policy intensity

$* p<0.05, * * * p<0.001$

Table 12 Placebo tests: Effects of higher education expansion on older cohorts aged 23-32 in 1998 from OLS regression models (base category is "Rate of expansion × aged 28-32 in 1998")

Years of education

(1)

(2)

(3)

Rate of expansion $\times$ cohorts

Rate of expansion $\times$ aged 23-27 in 1998

$-0.435 \quad-3.087$

Controls

Age at the time of the survey

Non-agricultural hukou

$\begin{array}{lll}\text { No } & \text { Yes } & \text { Yes } \\ \text { No } & \text { Yes } & \text { Yes } \\ \text { No } & \text { Yes } & \text { Yes } \\ \text { No } & \text { No } & \text { Yes } \\ \text { No } & \text { No } & \text { Yes } \\ \text { No } & \text { No } & \text { Yes } \\ 3418 & 3418 & 3418\end{array}$

Han majority

Interaction between exposure and 1998 GDP

Interaction between exposure and 1998 enrolment

Interaction between exposure and fertility policy intensity

$N$

3418

3418

All models control for one-year birth cohort and province fixed effects, age at the time of the survey, non-agricultural hukou, interactions between cohorts and provincial level GDP in 1998, tertiary enrolment in 1998, and fertility policy intensity. Standard errors are in parentheses and clustered by province 
Table 13 Effect of higher education expansion on men's educational attainment at each level: coefficients on the interactions between cohorts and provincial rate of expansion from Probit models (base category is "Rate of expansion $\times$ control")

Education attainment of males by level

(1) (2) (3) (4)

Tertiary High school Middle school Primary school

\begin{tabular}{lllll}
\hline Rate of expansion $\times$ cohorts & & & & \\
Rate of expansion $\times$ partially treated & 0.888 & 1.408 & 1.367 & 2.290 \\
& $(1.973)$ & $(1.933)$ & $(2.485)$ & $(4.709)$ \\
Rate of expansion $\times$ treated & $4.412^{*}$ & $3.731 \dagger$ & $4.859^{*}$ & 8.242 \\
\multirow{2}{*}{$\chi^{2}$ statistic } & $(2.059)$ & $(2.074)$ & $(2.467)$ & $(6.103)$ \\
$N$ & $5.21 \dagger$ & 3.58 & 3.13 & 1.09 \\
\hline
\end{tabular}

Standard errors are in parentheses

Control cohorts are aged 23-27, partially treated cohorts are aged 18-22, and treated cohorts are aged below 18 in 1998, just before the start of the expansion. All models control for 1-year birth cohort and province fixed effects, age at the time of the survey, non-agricultural hukou, interactions between cohorts and provincial level GDP in 1998, tertiary enrolment in 1998, and fertility policy intensity

The $\chi^{2}$-statistic tests the hypothesis that the coefficients on the interaction terms are jointly zero ${ }^{\dagger} p<0.10, * p<0.05$

Table 14 Falsification tests: effect of higher education expansion on number of children ever born (base category is "Rate of expansion $\times$ control"). Coefficients on the interactions between cohorts and provincial rate of expansion from Poisson models estimated among (1) full sample of somen (2) subsample of women with primary education and below and (3) subsample of women who had left school before 1999

Children ever born

\begin{tabular}{lll}
\hline (1) & $(2)$ & $(3)$ \\
Full sample & $\begin{array}{l}\text { women with primary } \\
\text { education and below }\end{array}$ & $\begin{array}{l}\text { women who had } \\
\text { left school before } \\
\end{array}$ \\
& & 1999
\end{tabular}

$\begin{array}{llll}\text { Rate of expansion } \times \text { cohorts } & & & \\ \text { Rate of expansion } \times \text { partially treated } & 0.522 & 0.676 & 0.351 \\ & (0.711) & (1.097) & (0.601) \\ \text { Rate of expansion } \times \text { treated } & 2.588^{* * * *} & -2.406 \dagger & -0.138 \\ & (0.719) & (1.337) & (0.944) \\ \chi^{2} \text { statistic } & 13.68 * * & 4.67 \dagger & 0.42 \\ N & 4566 & 1041 & 2145\end{array}$

Control cohorts are aged 23-27, partially treated cohorts are aged 18-22, and treated cohorts are aged below 18 in 1998, just before the start of the expansion. All models control for one-year birth cohort and province fixed effects

Standard errors are in parentheses and clustered by provinces. $\dagger p<0.10 * * p<0.01 * * * p<0.001$. The $\chi^{2}$ statistic tests the hypothesis that the coefficients on the interaction terms are jointly zero 
3 of "Appendix Table 14" showed no effect of higher education expansion on the number of children ever born among this subsample of women, lending further support to the exclusion restriction assumption that education only affects women's fertility through increasing their years of education.

Acknowledgements The author thanks the editor and the three anonymous reviewers for their helpful comments. The research reported in this publication was supported by The Eunice Kennedy Shriver National Institute of Child Health \& Human Development of the National Institutes of Health under Award Number P2CHD047879 and Award Number T32HD007163. The content is solely the responsibility of the authors and does not necessarily represent the official views of the National Institutes of Health.

Open Access This article is licensed under a Creative Commons Attribution 4.0 International License, which permits use, sharing, adaptation, distribution and reproduction in any medium or format, as long as you give appropriate credit to the original author(s) and the source, provide a link to the Creative Commons licence, and indicate if changes were made. The images or other third party material in this article are included in the article's Creative Commons licence, unless indicated otherwise in a credit line to the material. If material is not included in the article's Creative Commons licence and your intended use is not permitted by statutory regulation or exceeds the permitted use, you will need to obtain permission directly from the copyright holder. To view a copy of this licence, visit http://creativecommons.org/licen ses/by/4.0/.

\section{References}

Adserà, A. (2005). Vanishing children: From high unemployment to low fertility in developed countries. American Economic Review, 95(2), 189-193. https://doi.org/10.1257/000282805774669763

Adserà, A. (2011). Where are the babies? Labor market conditions and fertility in Europe. European Journal of Population/Revue Européenne De Démographie, 27(1), 1-32. https://doi.org/10.1007/ s10680-010-9222-X

Ahn, N., \& Mira, P. (2002). A note on the changing relationship between fertility and female employment rates in developed countries. Journal of Population Economics, 15(4), 667-682.

Akhtari, M., Bau, N., \& Laliberté, J.-W. (2019). Affirmative action and pre-college human capital (SSRN Scholarly Paper No. ID 3496598). Rochester, NY: Social Science Research Network. Retrieved 4 May 2020 from https://papers.ssrn.com/abstract=3496598.

Amin, V., \& Behrman, J. R. (2014). Do more-schooled women have fewer children and delay childbearing? Evidence from a sample of US twins. Journal of Population Economics, 27(1), 1-31. https:// doi.org/10.1007/s00148-013-0470-Z

Anderberg, D., \& Zhu, Y. (2014). What a difference a term makes: The effect of educational attainment on marital outcomes in the UK. Journal of Population Economics, 27(2), 387-419. https://doi.org/ 10.1007/s00148-013-0493-5

Anderson, T., \& Kohler, H.-P. (2015). Low fertility, socioeconomic development, and gender equity. Population and Development Review, 41(3), 381-407.

Andriano, L., \& Monden, C. W. S. (2019). The causal effect of maternal education on child mortality: Evidence from a quasi-experiment in Malawi and Uganda. Demography, 56(5), 1765-1790. https://doi.org/10.1007/s13524-019-00812-3

Angrist, J. D. (2001). Estimation of limited dependent variable models with dummy endogenous regressors. Journal of Business \& Economic Statistics, 19(1), 2-28. https://doi.org/10.1198/ 07350010152472571

Angrist, J. D., Imbens, G. W., \& Rubin, D. B. (1996). Identification of causal effects using instrumental variables. Journal of the American Statistical Association, 91(434), 444-455. https://doi.org/ $10.2307 / 2291629$

Angrist, J. D., \& Pischke, J.-S. (2009). Instrumental variables in action: Sometimes you get what you need. In Mostly harmless econometrics (pp. 113-219). Princeton University Press. https://doi. org/10.2307/j.ctvem4j72.11 
Angrist, J., Lavy, V., \& Schlosser, A. (2010). Multiple experiments for the causal link between the quantity and quality of children. Journal of Labor Economics, 28(4), 773-824. https://doi.org/ 10.1086/653830

Attané, I. (2012). Being a woman in China today: A demography of gender. China Perspectives, 2012(2012/4), 5-15. https://doi.org/10.4000/chinaperspectives.6013

Attané, I. (2016). Second child decisions in China. Population and Development Review, 42(3), 519536. https://doi.org/10.1111/j.1728-4457.2016.00151.x

Bankole, A., \& Singh, S. (1998). Couples' fertility and contraceptive decision-making in developing countries: Hearing the man's voice. International Family Planning Perspectives, 24(1), 15-24. https://doi.org/10.2307/2991915

Basten, S., \& Jiang, Q. (2015). Fertility in China: An uncertain future. Population Studies, 69(sup1), S97-S105. https://doi.org/10.1080/00324728.2014.982898

Becker, G. S. (1965). A theory of the allocation of time. The Economic Journal, 75(299), 493-517. https://doi.org/10.2307/2228949

Becker, G. S. (1969). An economic analysis of fertility. In Universities--National Bureau Committee for Economic Research (Ed.), Demographic and economic change in developed countries. National Bureau of Economic Research, distributed by Columbia University Press.

Becker, G. S. (1973). A theory of marriage: Part I. Journal of Political Economy, 81(4), 813-846. https:// doi.org/10.1086/260084

Becker, G. S. (1991). A treatise on the family. Harvard University Press.

Becker, G. S., \& Lewis, H. G. (1973). On the interaction between the quantity and quality of children. Journal of Political Economy, 81(2), S279-S288.

Becker, G. S., \& Tomes, N. (1976). Child endowments and the quantity and quality of children. Journal of Political Economy, 84(4), S143-S162.

Bhrolcháin, M. N., \& Beaujouan, É. (2012). Fertility postponement is largely due to rising educational enrolment. Population Studies, 66(3), 311-327. https://doi.org/10.1080/00324728.2012.697569

Bian, Y., \& Li, L. (2012). The Chinese general social survey (2003-8). Chinese Sociological Review, 45(1), 70-97. https://doi.org/10.2753/CSA2162-0555450104

Bittman, M., England, P., Sayer, L., Folbre, N., \& Matheson, G. (2003). When does gender trump money? Bargaining and time in household work. American Journal of Sociology, 109(1), 186-214. https:// doi.org/10.1086/378341

Black, S. E., Devereux, P. J., \& Salvanes, K. G. (2005). The more the merrier? The effect of family size and birth order on children's education. The Quarterly Journal of Economics, 120(2), 669-700. https://doi.org/10.1093/qje/120.2.669

Black, S. E., Devereux, P. J., \& Salvanes, K. G. (2008). Staying in the classroom and out of the maternity ward? The effect of compulsory schooling laws on teenage births*. The Economic Journal, 118(530), 1025-1054. https://doi.org/10.1111/j.1468-0297.2008.02159.x

Blossfeld, H., \& Kiernan, K. (2019). The new role of women: Family formation in modern societies. Routledge.

Blossfeld, H.-P., \& Huinink, J. (1991). Human capital investments or norms of role transition? How women's schooling and career affect the process of family formation. American Journal of Sociology, 97(1), 143-168.

Bongaarts, J. (2003). Completing the fertility transition in the developing world: The role of educational differences and fertility preferences. Population Studies, 57(3), 321-335. https://doi.org/10.1080/ 0032472032000137835

Braakmann, N. (2011). Female education and fertility: Evidence from changes in British compulsory schooling laws. Newcastle University.

Brand, J. E., \& Davis, D. (2011). The impact of college education on fertility: Evidence for heterogeneous effects. Demography, 48(3), 863-887. https://doi.org/10.1007/s13524-011-0034-3

Breierova, L., \& Duflo, E. (2004). The impact of education on fertility and child mortality: Do fathers really matter less than mothers? (Working Paper No 10513). National Bureau of Economic Research

Brinton, M. C., \& Oh, E. (2019). Babies, work, or both? Highly educated women's employment and fertility in East Asia. American Journal of Sociology, 125(1), 105-140. https://doi.org/10.1086/ 704369

Brown, P. H., \& Park, A. (2002). Education and poverty in rural China. Economics of Education Review, 21(6), 523-541. https://doi.org/10.1016/S0272-7757(01)00040-1 
Buathong, T., Striessnig, E., Testa, M. R., \& Muttarak, R. (2017). Too educated to want more children? Education and changing fertility intention in a low fertility context: The Case of Thailand. Presented at the PAA 2017 Annual Meeting, PAA. Retrieved 20 May 2021 from https://paa.confex. com/paa/2017/meetingapp.cgi/Paper/9786.

Cai, Y. (2010). China's below-replacement fertility: Government policy or socioeconomic development? Population and Development Review, 36(3), 419-440. https://doi.org/10.1111/j.1728-4457.2010. 00341.x

Cameron, A. C., \& Trivedi, K. P. (2009). Microeconometrics using stata, revised edition. Stata Press.

Cameron, A. C., \& Trivedi, P. K. (2013). Regression analysis of count data. Cambridge University Press.

Card, D. (2001). Estimating the return to schooling: Progress on some persistent econometric problems. Econometrica, 69(5), 1127-1160. https://doi.org/10.1111/1468-0262.00237

Carnoy, M., Loyalka, P., Dobryakova, M., Dossani, R., Froumin, I., Kuhns, K., et al. (2013). Universityexpansion in a changing global economy: Triumph of the BRICs? Stanford University Press.

Castanheira, H. C., \& Kohler, H.-P. (2017). Social determinants of low fertility in Brazil. Journal of Biosocial Science, 49(S1), S131-S155. https://doi.org/10.1017/S0021932017000396

Chen, Z., Ge, Y., Lai, H., \& Wan, C. (2013). Globalization and gender wage inequality in China. World Development, 44, 256-266. https://doi.org/10.1016/j.worlddev.2012.11.007

Cheng, C. (2019). Women's education, intergenerational coresidence, and household decision-making in China. Journal of Marriage and Family, 81(1), 115-132. https://doi.org/10.1111/jomf.12511

Chi, W., \& Li, B. (2014). Trends in China's gender employment and pay gap: Estimating gender pay gaps with employment selection. Journal of Comparative Economics, 42(3), 708-725. https://doi.org/ 10.1016/j.jce.2013.06.008

Chou, S.-Y., Liu, J.-T., Grossman, M., \& Joyce, T. (2010). Parental education and child health: Evidence from a natural experiment in Taiwan. American Economic Journal: Applied Economics, 2(1), 33-61. https://doi.org/10.2307/25760192

Cleland, J. (2002). Education and future fertility trends, with special reference to mid-transitional countries. In Completing the fertility transition. Population Bulletin of the United Nations

Cleland, J., \& Rodriguez, G. (1988). The effect of parental education on marital fertility in developing countries. Population Studies, 42(3), 419-442.

Cochrane, P. S. H. (1979). Fertility and education: What do we really know? The Johns Hopkins University Press.

Cohen, J. E., Kravdal, Ø., \& Keilman, N. (2011). Childbearing impeded education more than education impeded childbearing among Norwegian women. Proceedings of the National Academy of Sciences, 108(29), 11830-11835. https://doi.org/10.1073/pnas.1107993108

Conroy, R. M. (2005). Stings in the tails: Detecting and dealing with censored data. The Stata Journal, 5(3), 395-404. https://doi.org/10.1177/1536867X0500500308

Cygan-Rehm, K., \& Maeder, M. (2013). The effect of education on fertility: Evidence from a compulsory schooling reform. Labour Economics, 25, 35-48. https://doi.org/10.1016/j.labeco.2013.04.015

Ding, S., Dong, X., \& Li, S. (2009). Women's employment and family income inequality during China's economic transition. Feminist Economics, 15(3), 163-190. https://doi.org/10.1080/1354570080 2526541

Du, F., \& Dong, X. (2013). Women's employment and child care choices in urban China during the economic transition. Economic Development and Cultural Change, 62(1), 131-155. https://doi.org/10. $1086 / 671714$

Duflo, E. (2001). Schooling and labor market consequences of school construction in Indonesia: Evidence from an unusual policy experiment. The American Economic Review, 91(4), 795-813.

Duflo, E. (2004). The medium run effects of educational expansion: Evidence from a large school construction program in Indonesia. Journal of Development Economics, 74(1), 163-197. https://doi. org/10.1016/j.jdeveco.2003.12.008

Easterlin, R. A. (1975). An economic framework for fertility analysis. Studies in Family Planning, 6(3), 54-63. https://doi.org/10.2307/1964934

Easterlin, R. A., \& Crimmins, E. M. (1985). The fertility revolution: A supply-demand analysis. University of Chicago Press.

Ermisch, J. F. (1989). Purchased child care, optimal family size and mother's employment theory and econometric analysis. Journal of Population Economics, 2(2), 79-102. https://doi.org/10.1007/ BF00522403

Esping-Andersen, G. (2017). Education, gender revolution, and fertility recovery. Vienna Yearbook of Population Research, 15, 55-59. 
Esping-Andersen, G., \& Billari, F. C. (2015). Re-theorizing family demographics. Population and Development Review, 41(1), 1-31. https://doi.org/10.1111/j.1728-4457.2015.00024.x

Fan, C. C. (2005). Modeling interprovincial migration in China, 1985-2000. Eurasian Geography and Economics, 46(3), 165-184. https://doi.org/10.2747/1538-7216.46.3.165

Feeney, G., \& Yuan, J. (1994). Below replacement fertility in China? A close look at recent evidence. Population Studies, 48(3), 381-394.

Feng, X. (2017). 当代中国人的生育意愿:我们实际上知道多少? 社会科学, (08), 59-71.

Ferree, M. M. (1990). Beyond separate spheres: Feminism and family research. Journal of Marriage and Family, 52(4), 866-884. https://doi.org/10.2307/353307

Field, E., \& Ambrus, A. (2008). Early marriage, age of menarche, and female schooling attainment in Bangladesh. Journal of Political Economy, 116(5), 881-930. https://doi.org/10.1086/593333

Fort, M. (2012). Empirical evidence on the role of education in shaping female fertility patterns.

Fort, M., Schneeweis, N., \& Winter-Ebmer, R. (2016). Is education always reducing fertility? Evidence from compulsory schooling reforms. The Economic Journal, 126(595), 1823-1855. https://doi.org/ 10.1111/ecoj.12394

Geruso, M., \& Royer, H. (2018). The impact of education on family formation: Quasi-experimental evidence from the UK (Working Paper No. 24332). National Bureau of Economic Research. https:// doi.org/10.3386/w24332

Goldscheider, F., Bernhardt, E., \& Lappegård, T. (2015). The gender revolution: A framework for understanding changing family and demographic behavior. Population and Development Review, 41(2), 207-239. https://doi.org/10.1111/j.1728-4457.2015.00045.x

Grönqvist, H., \& Hall, C. (2013). Education policy and early fertility: Lessons from an expansion of upper secondary schooling. Economics of Education Review, 37, 13-33. https://doi.org/10.1016/j. econedurev.2013.07.010

Gu, B., Wang, F., Guo, Z., \& Erli, Z. (2007). China's local and national fertility policies at the end of the twentieth century. Population and Development Review, 33(1), 129-148. https://doi.org/10.1111/j. 1728-4457.2007.00161.x

Guo, Z., Gietel-Basten, S., \& Gu, B. (2019). The lowest fertility rates in the world? Evidence from the 2015 Chinese 1\% sample census. China Population and Development Studies, 2(3), 245-258. https://doi.org/10.1007/s42379-018-0012-1

Gustafsson, B., \& Li, S. (2000). Economic transformation and the gender earnings gap in urban China. Journal of Population Economics, 13(2), 305-329.

Han, H. (2010). Trends in educational assortative marriage in China from 1970 to 2000. Demographic Research, 22(24), 733-770.

Hannum, E. (2005). Market transition, educational disparities, and family strategies in rural China: New evidence on gender stratification and development. Demography, 42(2), 275-299. https://doi.org/ 10.1353/dem.2005.0014

Hare, D. (2016). What accounts for the decline in labor force participation among married women in urban China, 1991-2011? China Economic Review, 38, 251-266. https://doi.org/10.1016/j.chieco. 2016.01.004

Hazan, M., \& Zoabi, H. (2015). Do highly educated women choose smaller families? The Economic Journal, 125(587), 1191-1226. https://doi.org/10.1111/ecoj.12148

He, G., \& Wu, X. (2017). Marketization, occupational segregation, and gender earnings inequality in urban China. Social Science Research, 65, 96-111. https://doi.org/10.1016/j.ssresearch.2016.12. 001

Hermalin, A. I., \& Liu, X. (1990). Gauging the validity of responses to questions on family size preferences in China. Population and Development Review, 16(2), 337-354. https://doi.org/10.2307/ 1971594

Hoem, B., \& Hoem, J. M. (1989). The impact of women's employment on second and third births in modern Sweden. Population Studies, 43(1), 47-67. https://doi.org/10.1080/0032472031000143846

Hu, S., \& Yeung, W.-J.J. (2019). Education and childrearing decision-making in East Asia. Chinese Sociological Review, 51(1), 29-56. https://doi.org/10.1080/21620555.2019.1571903

Huang, W., Lei, X., \& Zhao, Y. (2016). One-child policy and the rise of man-made twins. Review of Economics and Statistics, 98(3), 467-476. https://doi.org/10.1162/REST_a_00567

Iacovou, M., \& Tavares, L. P. (2011). Yearning, learning, and conceding: Reasons men and women change their childbearing intentions. Population and Development Review, 37(1), 89-123. https:// doi.org/10.1111/j.1728-4457.2011.00391.x 
Imbens, G. W. (2014). Instrumental variables: An econometrician's perspective. Statistical Science, 29(3), 323-358.

Imbens, G. W., \& Angrist, J. D. (1994). Identification and estimation of local average treatment effects. Econometrica, 62(2), 467-475. https://doi.org/10.2307/2951620

Isen, A., \& Stevenson, B. (2010). Women's education and family behavior: Trends in marriage, divorce and fertility (Working Paper No. 15725). National Bureau of Economic Research. Retrieved 11 July 2019 from http://www.nber.org/papers/w15725.

Ji, Y. (2015a). Between tradition and modernity: "Leftover" women in Shanghai. Journal of Marriage and Family, 77(5), 1057-1073. https://doi.org/10.1111/jomf.12220

Ji, Y. (2015b). Asian families at the crossroads: A meeting of east, west, tradition, modernity, and gender. Journal of Marriage and Family, 77(5), 1031-1038. https://doi.org/10.1111/jomf.12223

Ji, Y., Wu, X., Sun, S., \& He, G. (2017). Unequal care, unequal work: Toward a more comprehensive understanding of gender inequality in post-reform urban China. Sex Roles, 77(11), 765-778. https://doi.org/10.1007/s11199-017-0751-1

Ji, Y., \& Yeung, W.-J.J. (2014). Heterogeneity in contemporary Chinese marriage. Journal of Family Issues, 35(12), 1662-1682. https://doi.org/10.1177/0192513X14538030

Jiang, Q., Li, Y., \& Sánchez-Barricarte, J. J. (2015). Fertility intention, son preference, and second childbirth: Survey findings from Shaanxi Province of China. Social Indicators Research, 125(3), 935953. https://doi.org/10.1007/s11205-015-0875-z

Jones, G. W. (2007). Delayed marriage and very low fertility in pacific Asia. Population and Development Review, 33(3), 453-478. https://doi.org/10.1111/j.1728-4457.2007.00180.x

Kamhöfer, D. A., \& Westphal, M. (2019). Fertility effects of college education: Evidence from the German educational expansion (Working Paper No. 316). DICE Discussion Paper. Retrieved 20 May 2021 from https://www.econstor.eu/handle/10419/201868.

Kan, K., \& Lee, M.-J. (2018). The effects of education on fertility: Evidence from Taiwan. Economic Inquiry, 56(1), 343-357. https://doi.org/10.1111/ecin.12492

Khanna, G. (2019). Does affirmative action incentivize schooling? Evidence from India. The Review of Economics and Statistics. https://doi.org/10.1162/rest_a_00848

Kırdar, M. G., Dayığlu, M., \& Koç, İ. (2018). The effects of compulsory-schooling laws on teenage marriage and births in Turkey. Journal of Human Capital, 12(4), 640-668. https://doi.org/10.1086/ 700076

Klesment, M., Puur, A., Rahnu, L., \& Sakkeus, L. (2014). Varying association between education and second births in Europe: Comparative analysis based on the EU-SILC data. Demographic Research, 31(27), 813-860. https://doi.org/10.4054/DemRes.2014.31.27

Knight, J., Deng, Q., \& Li, S. (2017). China's expansion of higher education: The labour market consequences of a supply shock. China Economic Review, 43, 127-141. https://doi.org/10.1016/j.chieco. 2017.01.008

Kramarz, F., Rosenqvist, O., \& Skans, O. N. (2021). How family background shapes the relationship between human capital and fertility. Journal of Population Economics. https://doi.org/10.1007/ s00148-021-00834-5

Kravdal, Ø. (1992). The emergence of a positive relation between education and third birth rates in norway with supportive evidence from the United States. Population Studies, 46(3), 459-475. https:// doi.org/10.1080/0032472031000146456

Kravdal, Ø., \& Rindfuss, R. R. (2008). Changing relationships between education and fertility: A study of women and men born 1940 to 1964. American Sociological Review, 73(5), 854-873.

Kugler, A. D., \& Kumar, S. (2017). Preference for boys, family size, and educational attainment in India. Demography, 54(3), 835-859. https://doi.org/10.1007/s13524-017-0575-1

Lappegård, T., \& Rønsen, M. (2005). The multifaceted impact of education on entry into motherhood. European Journal of Population/Revue Européenne de Démographie, 21(1), 31-49. https://doi.org/ 10.1007/s10680-004-6756-9

Lavely, W., \& Freedman, R. (1990). The origins of the Chinese fertility decline. Demography, 27(3), 357. https://doi.org/10.2307/2061373

Lefgren, L., \& McIntyre, F. (2006). The relationship between women's education and marriage outcomes. Journal of Labor Economics, 24(4), 787-830. https://doi.org/10.1086/506486

Leibenstein, H. (1974). An interpretation of the economic theory of fertility: Promising path or blind alley? Journal of Economic Literature, 12(2), 457-479.

Li, D., \& Tsang, M. C. (2003). Household decisions and gender inequality in education in rural China. China: An International Journal, 1(2), 224-248. 
Li, H., Liu, P. W., \& Zhang, J. (2012). Estimating returns to education using twins in urban China. Journal of Development Economics, 97(2), 494-504. https://doi.org/10.1016/j.jdeveco.2011.05.009

Li, H., Zhang, J., \& Zhu, Y. (2008). The quantity-quality trade-off of children in a developing country: Identification using Chinese twins. Demography, 45(1), 223-243. https://doi.org/10.1353/dem. 2008.0006

Li, S. D., \& Xing, C. (2010). China's higher education expansion and its labor market consequences.

Loyalka, P., Chu, J., Wei, J., Johnson, N., \& Reniker, J. (2017). Inequalities in the pathway to college in China: When do students from poor areas fall behind? The China Quarterly, 229, 172-194. https:// doi.org/10.1017/S0305741016001594

Luo, M. S., \& Chui, E. W. T. (2018). Gender division of household labor in China: Cohort analysis in life course patterns. Journal of Family Issues, 39(12), 3153-3176. https://doi.org/10.1177/01925 13X18776457

Marini, M. M. (1984). Women's educational attainment and the timing of entry into parenthood. American Sociological Review, 49(4), 491-511. https://doi.org/10.2307/2095464

Martin, T. C. (1995). Women's education and fertility: Results from 26 demographic and health surveys. Studies in Family Planning, 26(4), 187-202. https://doi.org/10.2307/2137845

Mason, K. O. (1987). The impact of women's social position on fertility in developing countries. Sociological Forum, 2(4), 718-745. https://doi.org/10.1007/BF01124382

Mason, K. O., \& Smith, H. L. (2000). Husbands' versus wives' fertility goals and use of contraception: The influence of gender context in five Asian countries. Demography, 37(3), 299-311. https://doi. org/10.2307/2648043

Maurer-Fazio, M., Connelly, R., Chen, L., \& Tang, L. (2011). Childcare, eldercare, and labor force participation of married women in urban China, 1982-2000. Journal of Human Resources, 46(2), 261-294. https://doi.org/10.3368/jhr.46.2.261

Maurer-Fazio, M., Hughes, J., \& Zhang, D. (2007). An ocean formed from one hundred rivers: The effects of ethnicity, gender, marriage, and location on labor force participation in urban China. Feminist Economics, 13(3-4), 159-187. https://doi.org/10.1080/13545700701439424

McCrary, J., \& Royer, H. (2011). The effect of female education on fertility and infant health: Evidence from school entry policies using exact date of birth. American Economic Review, 101(1), 158-195. https://doi.org/10.1257/aer.101.1.158

Merli, M. G., \& Morgan, S. P. (2011). Below replacement fertility preferences in Shanghai. Population, 66(3), 519-542.

Merli, M. G., \& Smith, H. I. (2002). Has the Chinese family planning policy been successful in changing fertility preferences? Demography, 39(3), 557-572. https://doi.org/10.1353/dem.2002.0029

Ministry of Education. (1998). Education statistics yearbook of China 1998. People's Education Press.

Ministry of Education. (2004). 1999年教育大事记. Official website of ministry of education. Retrieved 7 Aug 2019 from http://old.moe.gov.cn/publicfiles/business/htmlfiles/moe/moe_163/200408/3460. html.

Monstad, K., Propper, C., \& Salvanes, K. G. (2008). Education and fertility: Evidence from a natural experiment. The Scandinavian Journal of Economics, 110(4), 827-852.

Morgan, S. P., Zhigang, G., \& Hayford, S. R. (2009). China's below-replacement fertility: Recent trends and future prospects. Population and Development Review, 35(3), 605-629. https://doi.org/10. 1111/j.1728-4457.2009.00298.x

Mullahy, J. (1997). Instrumental-variable estimation of count data models: Applications to models of cigarette smoking behavior. The Review of Economics and Statistics, 79(4), 586-593.

Neels, K., Murphy, M., Bhrolcháin, M. N., \& Beaujouan, É. (2017). Rising educational participation and the trend to later childbearing. Population and Development Review, 43(4), 667-693. https://doi. org/10.1111/padr. 12112

Neiss, M., Rowe, D. C., \& Rodgers, J. L. (2002). does education mediate the relationship between IQ and age of first birth? A behavioural genetic analysis. Journal of Biosocial Science, 34(2), 259-275. https://doi.org/10.1017/S0021932002002596

Nisén, J., Klüsener, S., Dahlberg, J., Dommermuth, L., Jasilioniene, A., Kreyenfeld, M., et al. (2021). Educational differences in cohort fertility across sub-national regions in Europe. European Journal of Population, 37(1), 263-295. https://doi.org/10.1007/s10680-020-09562-0

Nisén, J., Martikainen, P., Kaprio, J., \& Silventoinen, K. (2013). Educational differences in completed fertility: A behavioral genetic study of Finnish male and female twins. Demography, 50(4), 13991420. https://doi.org/10.1007/s13524-012-0186-9

OECD. (2020). China. https://www.oecd-ilibrary.org/content/component/e8698c78-en. 
Ono, H. (2003). Women's economic standing, marriage timing, and cross-national contexts of gender. Journal of Marriage and Family, 65(2), 275-286. https://doi.org/10.1111/j.1741-3737.2003. 00275.x

Osili, U. O., \& Long, B. T. (2008). Does female schooling reduce fertility? Evidence from Nigeria. Journal of Development Economics, 87(1), 57-75. https://doi.org/10.1016/j.jdeveco.2007.10.003

Pimentel, E. E. (2016). Gender ideology, household behavior, and backlash in urban China. Journal of Family Issues. https://doi.org/10.1177/0192513X05283507

Piotrowski, M., Tong, Y., Zhang, Y., \& Chao, L. (2016). The transition to first marriage in China, 19662008: An examination of gender differences in education and Hukou status. European Journal of Population, 32(1), 129-154. https://doi.org/10.1007/s10680-015-9364-y

Ponczek, V., \& Souza, A. P. (2012). New evidence of the causal effect of family size on child quality in a developing country. Journal of Human Resources, 47(1), 64-106. https://doi.org/10.3368/jhr.47.1. 64

Qian, Y., \& Jin, Y. (2018). Women's fertility autonomy in urban China: The role of couple dynamics under the universal two-child policy. Chinese Sociological Review, 50(3), 275-309. https://doi.org/ $10.1080 / 21620555.2018 .1428895$

Qian, Y., \& Li, J. (2020). Separating spheres: Cohort differences in gender attitudes about work and family in China. China Review, 20(2), 19-51.

Qian, Y., \& Qian, Z. (2014). The gender divide in urban China: Singlehood and assortative mating by age and education. Demographic Research, 31, 1337-1364.

Raymo, J. M., \& Iwasawa, M. (2005). Marriage market mismatches in Japan: An alternative view of the relationship between women's education and marriage. American Sociological Review, 70(5), 801-822. https://doi.org/10.1177/000312240507000504

Raymo, J. M., \& Park, H. (2020). Marriage decline in Korea: Changing composition of the domestic marriage market and growth in international marriage. Demography, 57(1), 171-194. https://doi.org/ 10.1007/s13524-019-00844-9

Richter, K., Podhisita, C., Chamratrithirong, A., \& Soonthorndhada, K. (1994). The impact of child care on fertility in urban Thailand. Demography, 31(4), 651-662. https://doi.org/10.2307/2061797

Riederer, B., Buber-Ennser, I., \& Brzozowska, Z. (2019). Fertility intentions and their realization in couples: How the division of household chores matters. Journal of Family Issues, 40(13), 1860-1882. https://doi.org/10.1177/0192513X19848794

Rindfuss, R. R., \& Brewster, K. L. (1996). Childrearing and fertility. Population and Development Review, 22, 258-289. https://doi.org/10.2307/2808014

Rodgers, J. L., Kohler, H., McGue, M., Behrman, J. R., Petersen, I., Bingley, P., \& Christensen, K. (2008). Education and cognitive ability as direct, mediating, or spurious influences on female age at first birth: Behavior genetic models fit to Danish twin data. American Journal of Sociology, 114(S1), S202-S232. https://doi.org/10.1086/592205

Rosenzweig, M. R., \& Wolpin, K. I. (1980). Testing the quantity-quality fertility model: The use of twins as a natural experiment. Econometrica, 48(1), 227-240. https://doi.org/10.2307/1912026

Rosenzweig, M. R., \& Zhang, J. (2009). Do population control policies induce more human capital investment? Twins, birth weight and China's "One-Child" policy. The Review of Economic Studies, 76(3), 1149-1174.

Schultz, T. P. (1997). Chapter 8 demand for children in low income countries. In Handbook of population and family economics (Vol. 1, pp. 349-430). Elsevier. https://doi.org/10.1016/S1574-003X(97) 80025-6

Seeberg, V. (2014). Girls' schooling empowerment in rural China: Identifying capabilities and social change in the village. Comparative Education Review, 58(4), 678-707. https://doi.org/10.1086/ 677774

Shu, X., Zhu, Y., \& Zhang, Z. (2013). Patriarchy, resources, and specialization: Marital decision-making power in urban China. Journal of Family Issues, 34(7), 885-917. https://doi.org/10.1177/01925 $13 \mathrm{X} 12450001$

Sohn, H., \& Lee, S.-W. (2019). Causal impact of having a college degree on women's fertility: Evidence from regression kink designs. Demography. https://doi.org/10.1007/s13524-019-00771-9

Stange, K. (2011). A longitudinal analysis of the relationship between fertility timing and schooling. Demography, 48(3), 931-956. https://doi.org/10.1007/s13524-011-0050-3

Sun, M., \& Fan, C. C. (2011). China's permanent and temporary migrants: Differentials and changes, 1990-2000. The Professional Geographer, 63(1), 92-112. https://doi.org/10.1080/00330124.2010. 533562 
Sweeney, M. M. (2002). Two decades of family change: The shifting economic foundations of marriage. American Sociological Review, 67(1), 132-147. https://doi.org/10.2307/3088937

Testa, M. R. (2012). Couple disagreement about short-term fertility desires in Austria: Effects on intentions and contraceptive behaviour. Demographic Research, 26, 63-98.

Testa, M. R. (2014). On the positive correlation between education and fertility intentions in Europe: Individual- and country-level evidence. Advances in Life Course Research, 21, 28-42. https://doi. org/10.1016/j.alcr.2014.01.005

Testa, M. R., Cavalli, L., \& Rosina, A. (2014). The effect of couple disagreement about child-timing intentions: A parity-specific approach. Population and Development Review, 40(1), 31-53. https:// doi.org/10.1111/j.1728-4457.2014.00649.x

Tian, F. F. (2013). Transition to first marriage in reform-era urban China: The persistent effect of education in a period of rapid social change. Population Research and Policy Review, 32(4), 529-552. https://doi.org/10.1007/s11113-013-9272-y

Tropf, F. C., \& Mandemakers, J. J. (2017). Is the association between education and fertility postponement causal? The role of family background factors. Demography, 54(1), 71-91. https:// doi.org/10.1007/s13524-016-0531-5

UNESCO. (2020). China. World inequality database on education. https://www.education-inequaliti es.org/countries/china

United Nations, Department of Economic and Social Affairs, \& Population Division. (2019). World population prospects Highlights, 2019 revision Highlights, 2019 revision.

Willis, R. J. (1973). A new approach to the economic theory of fertility behavior. Journal of Political Economy, 81(2), S14-S64.

Windmeijer, F. A. G., \& Santos Silva, J. M. C. (1997). Endogeneity in count data models: An application to demand for health care. Journal of Applied Econometrics, 12(3), 281-294. https://doi. org/10.1002/(SICI)1099-1255(199705)12:3\%3c281::AID-JAE436\%3e3.0.CO;2-1

Wood, J., Klüsener, S., Neels, K., \& Myrskylä, M. (2020). Shifting links in the relationship between education and fertility. Population, Space and Place, 26(8), e2342. https://doi.org/10.1002/psp. 2342

Wood, J., Neels, K., \& Kil, T. (2014). The educational gradient of childlessness and cohort parity progression in 14 low fertility countries. Demographic Research, 31, 1365-1416.

Wu, X., \& Zhang, Z. (2010). Changes in educational inequality in China, 1990-2005: Evidence from the population census data. In Globalization, changing demographics, and educational challenges in East Asia (Vols. 1-0, Vol. 17, pp. 123-152). Emerald Group Publishing Limited. Retrieved 23 Aug 2016. http://www.emeraldinsight.com/doi/abs/. https://doi.org/10.1108/ S1479-3539(2010)0000017007.

Yeung, W.-J.J. (2013). Higher education expansion and social stratification in China. Chinese Sociological Review, 45(4), 54-80. https://doi.org/10.2753/CSA2162-0555450403

Yeung, W.-J.J., \& Hu, S. (2016). Paradox in marriage values and behavior in contemporary China. Chinese Journal of Sociology, 2(3), 447-476. https://doi.org/10.1177/2057150X16659019

Yu, J., \& Xie, Y. (2015). Changes in the determinants of marriage entry in post-reform urban China. Demography, 52(6), 1869-1892. https://doi.org/10.1007/s13524-015-0432-z

Zeng, Y., \& Hesketh, T. (2016). The effects of China's universal two-child policy. The Lancet, 388(10054), 1930-1938. https://doi.org/10.1016/S0140-6736(16)31405-2

Zhang, J. (1990). Socioeconomic determinants of fertility in China. Journal of Population Economics, 3(2), 105-123. https://doi.org/10.1007/BF00187287

Zhang, J., Han, J., Liu, P.-W., \& Zhao, Y. (2008). Trends in the gender earnings differential in urban China, 1988-2004. Industrial and Labor Relations Review, 61(2), 224-243.

Zhang, Q. F. (2013). Gender disparities in self-employment in urban china's market transition: Income inequality, occupational segregation and mobility processes. The China Quarterly, 215, 744-763. https://doi.org/10.1017/S030574101300074X

Zhang, Y., \& Hannum, E. (2015). Diverging fortunes: The evolution of gender wage gaps for singles, couples, and parents in China, 1989-2009. Chinese Journal of Sociology, 1(1), 15-55. https:// doi.org/10.1177/2057150X14568769

Zhang, Y., Hannum, E., \& Wang, M. (2008). Gender-based employment and income differences in urban China: Considering the contributions of marriage and parenthood. Social Forces, 86(4), 1529-1560. https://doi.org/10.1353/sof.0.0035 
Zhang, Y., Kao, G., \& Hannum, E. (2007). Do mothers in rural china practice gender equality in educational aspirations for their children? Comparative Education Review, 51(2), 131-157. https:// doi.org/10.1086/512023

Zhao, Z. (2015). Closing a sociodemographic chapter of Chinese history. Population and Development Review, 41(4), 681-686. https://doi.org/10.1111/j.1728-4457.2015.00090.x

Zhao, Z., \& Zhang, G. (2018). Socioeconomic factors have been the major driving force of China's fertility changes since the mid-1990s. Demography, 55, 733-742. https://doi.org/10.1007/ s13524-018-0662-y

Zheng, X., Tan, L., Ren, Q., Cui, Z., Wu, J., Lin, T., et al. (2012). Trends in contraceptive patterns and behaviors during a period of fertility transition in China: 1988-2006. Contraception, 86(3), 204-213. https://doi.org/10.1016/j.contraception.2011.12.006

Zheng, Z. (2014). 生育意愿的测量与应用. 中国人口科学, (06), 15-25+126.

Zhenzhen, Z., Cai, Y., Feng, W., \& Baochang, G. (2009). Below-replacement fertility and childbearing intention in Jiangsu province China. Asian Population Studies, 5(3), 329-347. https://doi.org/10. $1080 / 17441730903351701$

Zuo, J. (2003). From revolutionary comrades to gendered partners: Marital construction of breadwinning in post-mao urban China. Journal of Family Issues, 24(3), 314-337. https://doi.org/10.1177/01925 $13 \mathrm{X} 02250888$

Zuo, J., \& Bian, Y. (2001). Gendered resources, division of housework, and perceived fairness: A case in urban China. Journal of Marriage and Family, 63(4), 1122-1133. https://doi.org/10.1111/j.17413737.2001.01122.x

Publisher's Note Springer Nature remains neutral with regard to jurisdictional claims in published maps and institutional affiliations. 